\title{
SIEDZIBY PAŃSKIE NA ŚLĄSKU W ŚWIETLE ŹRÓDEŁ PISANYCH. STUDIUM NAD ŚREDNIOWIECZNĄ NOMENKLATURĄ
}

\author{
MANOR HOUSES IN SILESIA IN LIGHT OF WRITTEN SOURCES: \\ A STUDY OF MEDIEVAL NOMENCLATURE
}

The subject of this study is the nomenclature used in medieval written sources for small feudal residences. The majority of them are private foundations of vassals to the duke, i.e., knights and citizens of Wroclaw. A few examples are seats of village administrators, as well as rural mansions of knightly orders. Also examined are smaller objects (most having special functions) built by territorial rulers - namely, Silesian dukes and bishops of Wrocław. These objects were clearly different in their scale from the stately brick castles that played the role of princely residences or were otherwise part of the country's administrative structure. In light of the materials collected, small feudal residences were mentioned in medieval Silesian written sources as: curia/Hof, curia habitationis, curia murata/gemauerte Hof, castrum/Burg/Haus, fortalicium/ Feste, propugnaculum/Bergfried, turris/Turm, Gesesse, Sitz, Rittersitz.

KEY WORDS: Śląsk, Silesia, history, medieval archaeology, castles, manor houses

W środowisku mediewistów powszechna jest wiedza o bogactwie średniowiecznego piśmiennictwa śląskiego. Z oczywistych względów sięgają do niego przede wszystkim historycy, rzadziej przedstawiciele innych dyscyplin. Ze źródeł pisanych chętnie korzystają kastellolodzy - głównie archeolodzy i architekci - ,wyłuskując” z nich informacje odnośnie chronologii i fundatorów obiektów, czy też kontekstu historycznego w jakim je budowano.

Przedmiotem niniejszego opracowania jest nomenklatura stosowana $\mathrm{w}$ średniowiecznych źródłach pisanych w odniesieniu do niewielkich siedzib pańskich. Ich znakomita większość to fundacje prywatne książęcych wasali, to jest rycerzy i mieszczan wro- cławskich. Pojedyncze przykłady to siedziby sołtysów czy wiejskie dwory zakonów rycerskich. Prócz tego uwzględniono kilka obiektów zbudowanych przez władców terytorialnych. Założenia te bowiem, pod względem formalnym, wyraźnie różniły się od zamków państwowych z rozwiniętą architekturą murowaną - pełniących funkcję rezydencji i odgrywających ważną rolę w strukturze administracyjnej kraju, w niemieckiej literaturze określanych jako Landesburgen. Wykorzystane w artykule zameczki książęce i biskupie to w większości obiekty wiejskie, jedynie trzy z nich (Jędrzychów, Lubrza, Woźniki) związane były z niewielkimi miasteczkami. Znajdziemy wśród nich przykłady warowni, które odgrywały istotną rolę 
w kształtowaniu sieci osadniczej (tzw. zamki kolonizacyjne), zbudowane podczas konfliktów militarnych (zamki okupacyjne) oraz pełniące funkcję wiejskich dworów książęcych i biskupich.

Wiodąca rola Śląska w rozwoju budownictwa obronno-rezydencjonalnego była wielokrotnie podkreślana w literaturze. W porównaniu $\mathrm{z}$ innymi historycznymi regionami dawnego Królestwa Polskiego, to właśnie stąd znanych jest najwięcej reliktów średniowiecznych zamków, w tym założeń najstarszych (Guerquin 1984, 25; Kajzer, Kołodziejski, Salm 2001, 30-34; Boguszewicz 2001; Chorowska 2002). Powyższą uwagę odnieść można także do niewielkich siedzib feudalnych ${ }^{1}$. Pod względem formalnym reprezentowały one różne rozwiązania, a ich relikty najczęściej manifestują się w terenie jako tzw. grodziska stożkowate, w literaturze europejskiej określane jako obiekty typu motte. Założenia murowane to przeważnie wieże mieszkalne, niekiedy także budowane na ziemnych kopcach. Rzadsze i zwykle młodsze są obiekty o bardziej rozwiniętych formach architektonicznych, takie jak jedno czy dwuskrzydłowe dwory (Rozpędowski 1978; Chorowska 2003, 131-151, 166194; Boguszewicz 2012; Nowakowski 2017a; Błoniewski 2017).

W dotychczasowej historiografii problem średniowiecznej nomenklatury dotyczącej budownictwa obronno-rezydencjonalnego był rzadko przedmiotem osobnych studiów (Kunstmann 1967, 1-34; Marciniak 1991; Nowak, Szymczak 1993). Dla Śląska próbę analizy terminologii podjęto przy okazji prac nad obiektami typu motte (Nowakowski 2017a, 79-89). Wiele do dyskusji wniosły także publikacje Mateusza Golińskiego o konfliktach między książętami śląskimi a biskupami wrocławskimi i wsparciu przez wrocławian wypraw organizowanych przeciw zamkom (Goliński 2005; 2014). Ostatnio średniowiecznej nomenklaturze obiektów obronnych uwagę poświęcił Dariusz Poliński, który wrócił do podjętej przed laty dyskusji na temat desygnatów terminów „,gród” i ,zamek” (Poliński 2018, 47-51).

1 Badania nad początkami siedzib możnowładczych w Polsce wykazały, że ich najstarszych reliktów w pierwszym rzędzie należy szukać w obrębie policentrycznych ośrodków wczesnomiejskich (przedlokacyjnych). Kilka takich dworów, przede wszystkim z XII-wiecznych źródeł pisanych, znamy z Wrocławia (por. Boguszewicz 2012, 27-36, tam starsza literatura), jednak z racji ich lokalizacji w ramach wspomnianych struktur osadniczych, nie będą omawiane w niniejszym artykule.
Kluczowe informacje na temat interesujących nas obiektów pozyskano ze źródeł masowych. W pierwszym rzędzie były to edycje landbuchów księstw świdnickiego i jaworskiego (LKŚJ, I: 1366-1376; II i III: 1385-1407), regesty dokumentów Ludwika I brzeskiego (UHLB: 1331-1398), regesty listów lennych księstwa żagańskiego (RSL) z lat 1474 i 1508 (zawierające także wcześniejsze dokumenty), a także spisy szlachty księstwa oleśnickiego z lat 1530 i 1567. Wiele istotnych danych pozyskano z edycji i regestów dokumentów śląskich (SUb, I-VI: do roku 1300; RS: 1301-1342; Rś: 1343-1360). Z materiałów dotychczas niepublikowanych kluczowe znaczenie miały informacje z kopiarza dokumentów księstwa wrocławskiego, czyli tzw. Repertorium Frobenianum (RF). Nieliczne, ale interesujące dane, pochodzą także ze źródeł narracyjnych, w tym przede wszystkim z Księgi Henrykowskiej (KH). W przypadku informacji o interesujących nas obiektach zawartych w regestach, w miarę możliwości starano się dotrzeć do dokumentów oryginalnych, których największe zasoby przechowywane są w Archiwum Państwowym i Archiwum Archidiecezjalnym we Wrocławiu. Wartość nie do przecenienia miały materiały zebrane w trakcie prac nad Stownikiem wsi ślaskich w średniowieczu, projektu realizowanego od kilku lat przy wrocławskim oddziale IAE PAN. Chcąc w pełni zobrazować znaczenie średniowiecznych terminów stosowanych w odniesieniu do niewielkich siedzib pańskich, starałem się je połączyć z konkretnymi przykładami obiektów zachowanych $\mathrm{w}$ terenie lub znanych $\mathrm{z}$ archiwaliów. W tym wypadku obficie korzystałem z najnowszego dorobku archeologów i architektów (Chorowska 2003; Nowakowski 2008; 2017a; LegutPintal 2017; Błoniewski 2017) ${ }^{2}$.

\section{Curia/Hof}

Niewielkie siedziby pańskie w źródłach śląskich najczęściej wymieniane były jako dwory. Termin ten wielokrotnie omawiano w literaturze, w której zwracano uwagę na jego wieloznaczność. Stosowane w średniowiecznych dokumentach określenie dwór [curia/ Hof] miało nawet kilkanaście znaczeń. W przypadku wiejskich nieruchomości kryć się za nim mogły także dwory sołtysie i plebańskie, folwarki, a nawet zagro-

W tym miejscu chciałbym serdecznie podziękować Panu dr. Piotrowi Błoniewskiemu za udostępnienie mi swojej dotychczas niepublikowanej dysertacji doktorskiej. 
dy kmiece (Stownik łaciny..., II, 1502-1509; Deutsches Wörterbuch...,X, 1655-1656; Marciniak1991,162-163; Marciniak-Kajzer 2011, 11-12).

Najstarsze informacje o XIII-wiecznych dworach odnoszą się do założeń książęcych i biskupich. W 1228 r. był wzmiankowany dwór Henryka Brodatego [curia ducis] w Leśnicy koło Wrocławia. Był to zapewne obiekt o wysokim standardzie, o czym może zaświadczać znajdujące się w nim pomieszczenie określone jako caminata, w którym książę wystawił dokument. Mimo starań ze strony archeologów i architektów, nie udało się - jak dotąd - natrafić na relikty założenia z początku XIII w. (SUb, I, nr 278; 293; Chorowska 2003, 64-66). W Księdze Henrykowskiej odnajdujemy natomiast informację, że książę Henryk planował także zbudować dwór w Henrykowie, od czego odwiedli go biskupi wrocławscy. Dla śląskiego władcy obiekt ten miał chyba szczególne znaczenie, co sugeruje użyte w odniesieniu do niego wyjątkowe określenie curia regale. W opowieści opata Piotra pojawia się też wzmianka, że około 1241-1244 r. książę Bolesław Rogatka miał dwór [curia] w Dziewinie koło Ścinawy. Niestety, nie wiadomo nic o jego wyglądzie. Być może lokalizacja pokrywała się ze znanymi $z$ danych archiwalnych reliktami założenia warownego z XIV w., zbudowanego na krawędzi wysoczyzny Odry (KH, 16/120, 44/143; Nowakowski 2008, 198, 330, 465-467; Adamska 2019, 94). Równie zagadkowo przedstawia się sprawa dworu Władysława opolskiego w Gołkowicach pod Byczyną, wzmiankowanego tylko raz, w 1278 r. [curia nostra circa Golkowicz], przy okazji stacjonowania tam księcia. W okolicy znane jest słabo rozpoznane grodzisko stożkowate, jednak datowane na XIV w. (SUb, IV, nr 335; Nowakowski 2017a, 303-304). W 1262 r. poświadczony był dwór biskupów wrocławskich w Pogalewie Małym koło Wołowa [curia episcopalis in Pogaleu]. Kwestią otwartą pozostaje, czy już wówczas było to założenie obronne. Jako takie poświadczone było w 1344 r., kiedy to książę Konrad II oleśnicki oblegał i zdobył curiam dictam Pogalow. Być może reliktem najstarszego dworu jest rozległe plateau otoczone fosą, którego centralną część zajmuje okazały obiekt typu motte, datowany na XIII-XIV w. (SUb, III, nr 421; UGBB, nr 274; Nowakowski 2017a, 195, 394)33.

3 Cyfrowe wizualizacje uwzględnionych w artykule obiektów w Bełczu Małym, Lubnowie, Kręsku, Maniowie Małym (jako Maniów), Mokrej, Katzenschinder (jako Chwalimierz), Pogalewie Małym, Warkoczu, dostępne
W Oleśnicy Małej koło Oławy w 1260 r. znajdował się dwór templariuszy [curia cruciferorum]. Na początku XIV w. majątek ten przejęli joannici, którym Ludwik I brzeski w 1377 r. zezwolił na nową lokację wsi na miejscu dworu [hofe zur Oelsen]. Poza gospodarstwem własnym templariuszy, a następnie joannitów, funkcjonował tam zapewne jakiś ufortyfikowany obiekt, skoro książę wyraził też zgodę na budowę nowego obronnego dworu [feste hoff], a jednocześnie zastrzegł sobie prawo kwaterunku (SUb, III, nr 339; UHLB, nr 2829; Eistert 1936, 44; Heś 2007, 220; Adamska 2019, 219). Z kolei z Wojszycami koło Wrocławia łączy się dwór Krzyżaków [curia fratrum cruciferorum], wymieniony w 1273 r. Zarządzający nim komendator Johannes de Zittin był poświadczony w latach 1337-1338, natomiast w 1336r. książę Bolko II ziębicki wystawił tu dokument [in curia Woyshicz]. Cztery lata później Jan Luksemburski przekazał za wierne służby Hermanowi de Essin dobra w Wojszycach, co w 1342 r. potwierdził margrabia Karol. Hermann oraz jego następcy otrzymali wszystkie dobra należące do dworu [Hofe Woischwitz] wraz z samym dworem [mit dem Hofe selbst] (SUb, IV, nr 212; RS, nr 5726, 5780, 5999, 6042, 6490, 6849; Goliński 1991). Najpewniej przy gospodarczym dworze funkcjonowała jakaś ufortyfikowana siedziba, o czym pośrednio może poświadczać zatrzymanie się tu księcia ziębickiego. Położony na terenie wsi obiekt mieszkalny [Gesäß] wymieniony był po raz pierwszy w $1418 \mathrm{r}$. Jego fundatorami byli jednak najpewniej mieszczanie wrocławscy - Beierowie - do których dobra wojszyckie należały od 1371 r. (RF, IV, 2991-2998).

Drugiej połowy XIII w. sięgają początki dworu biskupiego w Skoroszowie koło Rychtala. Należącą od 1249 r. do wrocławskich ordynariuszy wieś w 1271 r. spustoszyły wojska Bolesława Wstydliwego. Jako curia Scorossow była wymieniona w datowanej na początek XIV w. księdze uposażenia biskupstwa wrocławskiego. Być może decyzję o ufortyfikowaniu dworu podjęto po najeździe wojsk krakowskich. W 1399 r. biskup Wacław sprzedał, z prawem wykupu, Gumbertowi von Slywyn folwark Skoroszów cum fortalitio sive curia (SUb, II, nr 364; IV, nr 130; Lf, B, 189, 241a, 276; AAWr., dok. alf., sygn. JJ 54; Heyne I, 288-289). Pozostałością tego założenia może być widoczny na skaningu laserowym częściowo zachowany kopiec otoczony fosą, przylegający od południa do barokowego pałacu. Niejasne są początki

są w wirtualnym katalogu śląskich obiektów obronnych: http://www.odgrodudozamku.pl/ 
dworu w Chróścinie koło Grodkowa. W 1344 r. biskup Przecław kupił od Bolesława III legnicko-brzeskiego weichbild grodkowski, a w sporządzonym w tym samym roku rejestrze dóbr wymieniono Falkenow curia in Crosschin. W 2. poł. XIV w. posiadłości we wsi trzymały różne rodziny rycerskie, w tym Heynczko z Wilemowic, który w 1379 r. sprzedał Henrykowi ze Smolic ogród położony przy jego dworze [Hof]. Wobec słabego rozpoznania archeologicznego grodziska stożkowatego z Chróściny, datowanego na XIV-XVI w., kwestią otwartą pozostaje, czy kryje ono pozostałości dworu z 1. poł. XIV w. (Lf, F, 16; QGNB, nr 927; Nowakowski 2017a, 282).

Prawdopodobnie fundacjami książęcymi były także poświadczone źródłowo dwory w Rożnowie i Karnkowie koło Strzelina. Pierwszy z nich, wraz z sołectwem i folwarkiem, w 1349 r. Mikołaj ziębicki oddał za długi w dożywocie Maciejowi z Trenczyna. Z kolei Bolko III ziębicki w 1371 r. sprzedał Henrykowi Czamborowi wieś i folwark Karnków wraz $\mathrm{z}$ dworem i obwarowaniami [Hof und Wehrunge]. $\mathrm{Z}$ obu miejscowości znane są relikty, niestety bliżej nierozpoznanych, założeń typu motte. Obiekt z Rożnowa to niewielki kopiec otoczony fosą, natomiast w Karnkowie zachowane jest duże, dwuczłonowe założenie z kopcem i wydzielonym podzamczem otoczonym fosą i wałem (Nowakowski 2017a, 323-324, 410; Adamska 2019, 111-113).

Prawdopodobnie funkcję biskupiego myśliwskiego dworu pełnił obiekt z Wierzbna koło Otmuchowa, wymieniony w latach 1317-1318 jako Wirbna curia propre Nizam i ponownie w 1373 r. Najpewniej już w XIV w. funkcjonował tam obiekt obronny, w $1425 \mathrm{r}$. poświadczony jako fortalicium bonum. Obecnie niemal całkowicie zniszczone założenie identyfikuje się z barokowym pałacem myśliwskim, położonym w kompleksie leśnym na północ od wsi Wierzbno (RSB, 42; QGNB, nr 446; Reg. Wrat., 244; Legut-Pintal 2017, 157-178; Goliński 2014, 824). Jednoznacznie jako dwór myśliwski [curia venationis] należący do książąt oleśnickich, w 1405 r. nazwano obiekt z Ostrowiny koło Oleśnicy. Być może jego reliktem było zachowane do niedawna niewielkie grodzisko stożkowatego (Haeusler 1883, 420; Nowakowski 2017a, 194, $380)$.

W źródłach pisanych odnajdujemy znacznie więcej informacji o wiejskich dworach lenników książęcych: rycerzy, mieszczan, wójtów i sołtysów. Prowadzone w krajach ościennych badania archeologiczne wykazały, że wczesne przykłady dworów, pod względem organizacji przestrzennej, charakteryzowały się przenikaniem funkcji mieszkalnych i gospodarczych. Były to założenia o dość dużej powierzchni, ogrodzone płotem, palisadą, a niekiedy płytkim rowem (Boguszewicz 2012, 112-118, tam dalsza literatura). Relikty tego typu założenia z 2. poł. XIII w. odkryto w sąsiedztwie kościoła w Wierzbnej koło Świdnicy (Boguszewicz 2005, 292-296; 2012, 125-126). Wspomniana już wieloznaczność terminu curia, jak i słaby stopień zaawansowania badań archeologicznych najstarszych wiejskich siedzib feudalnych na Śląsku sprawia, że jednoznaczne określenie, co kryło się pod tym pojęciem, jest na obecnym etapie badań praktycznie niemożliwe. Uwaga ta dotyczy przede wszystkim wczesnych dworów, wzmiankowanych w źródłach incydentalnie ${ }^{4}$.

Drugiej połowy XIII w. sięgają zapewne początki dworu z Osetna koło Góry. Wymieniony w 1327 r. obiekt [curia Ossethna] należał wówczas do Jana ścinawskiego. Nie wiemy, w jakich okolicznościach dwór znalazł się w rękach księcia, choć najpewniej przejął go prawem kaduka, po wygaśnięciu rodu panów z Osetna. Ich ostatni przedstawiciel Przecław w źródłach występował do 1326 r. Obiekt ten prawdopodobnie był położony $\mathrm{w}$ miejscu obecnego renesansowego dworu, w sąsiedztwie kościoła, również przypisywanego fundacji panów z Osetna (RS, nr 4499, 4600; Nowakowski 2008, 200, 515-516). Z Sadowic pod Wrocławiem pisał się w 1306 r. rycerz Stosz. Trzydzieści lat później Klimka, wdowa po Dytryku z Sadowic, zastawiła 11/2 łanu, parcelę [Gehöft] i ogród, położone naprzeciwko działu Przybka, nad rzeką Leśnicą. W 1342 r. Karol Luksemburski zezwolił rycerzowi Przybkowi z Sadowic i jego żonie, w razie ich bezpotomnej śmierci, na przekazanie folwarku we wsi Zygfrydowi von Schiraw. Cztery lata później Jenchin z Sadowic zapisał żonie, jako oprawę wdowią, między innymi curiam suam super Lessna jacentem. Bernhard von Schiraw w 1369 r. zrezygnował na rzecz braci z kawałka lasu położonego circa prenicies retro curiam (RS, nr 2798, 5730, 6872; RF, III, 266-267). Zagadkowe prenicies zapisane w nowożytnym odpisie regestu dokumentu, to chyba skrót od premunicies, oznaczającego jakiś rodzaj umocnień. Być może chodziło o nasyp lub wały zabezpieczające dwór przed wylewami rzeki.

Interesujący przekaz dotyczy znanych z Księgi Henrykowskiej dziedziców Czesławic. Na początku

4 1306: Domasław k. Wrocławia (RS, nr 2898); 1337 : Kowale k. Wrocławia (RS, nr 5983); 1359: Marcinkowice k. Wrocławia (RF, II, 742). 
XIV w. nastąpiło rozdrobnienie majątku Henryka, który, według opata cystersów, miał się za rycerza. Znany tylko z niemieckiego regestu dokument z $1313 \mathrm{r}$. potwierdzał, że Jeszko z Czesławic, syn Ścibora, w imieniu swoim i brata Alberta, sprzedał klasztorowi w Henrykowie zbytek porośnięty lasem, położony za jego zagrodą, a także cały plac dworu [dem ganzen Platze des Hofes], łąkę i 4 ogrody (RS, nr 3336). W niedalekich Raczycach siedziało natomiast czterech braci, według relacji henrykowskiego zakonnika, niegdyś komorników na dworze książęcym. W wyniku podziału majątku Gniewko otrzymał czwartą część, podczas gdy trzej pozostali bracia mieszkali w jednym domku [domicilium], na wspólnym chlebie. Dwóch z nich wkrótce zmarło bezpotomnie, przy czym Jan zginął nagłą śmiercią, gdy pilnował własnego konia za swoim dworem [retro curiam suam] (KH, 14/118, 79/175; RS, nr 3336; Adamska 2019, 286).

W pierwszej połowie XIV w. dobra cząstkowe znajdowały się także w Lubnowie koło Urazu, które w 1336 r. posiadali Piotr Prittwitz i Hanko, syn Jana Cruso. Drugi z wymienionych wydzierżawił Mikołajowi z Radecza 3 łany i inne dobra, w tym swój dwór [curiam suam]. Z kolei w 1351 r. Klaus z Lubnowa sprzedał piszącemu się również stamtąd Mikołajowi oraz Konradowi z Wołowa curiam suam i 2 łany. $\mathrm{Na}$ terenie wsi są zachowane relikty dworu na kop$\mathrm{cu}$, jednak badania archeologiczne wykazały, że są to pozostałości siedziby starosty wołowskiego Hansa Debitscha z przełomu XV i XVI w. (RF, II, 642, 647; Adamska 2006; Nowakowski 2017a, 208, 350-351). W 1338 r. mieszczanin wrocławski Jan Sommerfeld zapisał żonie połowę wsi Brzezina, położoną contra curiam suam. Wydawcy niemieckich regestów uznali, że chodziło o parcelę (Gehöft), natomiast przy okazji sprzedaży tamtejszych dóbr przez Franzke Sommerfelda w 1383 r. wymieniono folwark (RF, I, 52b, 53a; $\mathrm{RS}, \mathrm{nr}$ 6032). Bliżej nierozpoznane są niestety zachowane we wsi relikty murowanego dworu na kopcu otoczonym głęboką fosą i częściowo zachowanym wałem zewnętrznym.

Między Wrocławiem a Trzebnicą leży wieś Bukowina, w której w 1339 r. znajdowała się curia, należąca do dziedzicznych panów wsi - braci Mikołaja i Jana zw. von Löwenberg. Do nich należały także 3 wolne łany i parcele sołeckie oraz ogród, a wspomniany dwór był położony zaraz obok nich (RS, nr 6284). Być może obiekt ten znajdował się we wschodniej części wsi, gdzie do czasów nowożytnych zachowana była siedziba pańska otoczona fosą (ryc. 1:a). Co najmniej pierwszej połowy XIV w. sięgają także początki siedziby rodziny von Prittwitz w Kręsku koło Brzegu Dolnego. Obiekt jako Hofe wymieniony był kolejno w 1342, 1358 i 1401 r. Jego reliktem jest datowane na XIV-XV w. grodzisko stożkowate, zbudowane na miejscu wczesnośredniowiecznego grodu (RS, nr 6826; RF, I, 510; Nowakowski 2017a, 339-340). Michał z Sokolnik w 1347 r. sprzedał Henrykowi Quass i wójtowi niemodlińskiemu Piotrowi swoje posiadłości w Magnuszowiczkach koło Niemodlina wraz z dworem [Hof], wsią i karczmą. Także ten obiekt identyfikować należy zapewne z reliktami grodziska stożkowatego z XIV w., położonymi na zachód od wsi, w obrębie podmokłej doliny Ścinawy (RSW, nr 16; Nowakowski 2017a, 356-357).

Kilka dworów położonych nad Czarną Wodą w księstwie legnickim wyliczono w 1359 r., na okoliczność układu zawartego między książętami Wacławem I i Ludwikiem I w sprawie podziału ojcowizny. Wśród nich znalazły się hofen w Bukownej koło Lubina, Zamienicach i Rokitkach koło Chojnowa, dwór Pecze von Schellendorfa w Gniewomierzu, a także niewymieniony z nazwy dwór Henkina Budziwoja (Lehns., I, 337-338). Część z rzeczonych założeń nie przetrwała do dziś, natomiast obiekty zachowane w terenie (Bukowna, Rokitki) to jednoczłonowe grodziska stożkowate (Nowakowski 2017, 277-278, 407408).

Kolejne liczne wzmianki o wiejskich dworach rycerskich znajdujemy $\mathrm{w}$ przekazach z 2. połowy XIV w. i XV w. ${ }^{5} \mathrm{~W}$ Jaźwinie koło Dzierżoniowa

5 1360: Zwierzyniec k. Lubina (SWŚ, I, s. 188); 1362: Budziwojów k. Chojnowa (UHLB, nr 392); 1362: Bukowna k. Lubina (UHLB, nr 443); 1363: Chwalimierz k. Środy Śląskiej (RF, I, s. 130); 1366: Zawadka k. Strzegomia (LKŚJ, I, nr 26); 1371: Roztoka k. Świdnicy (LKŚJ, I, nr 500); 1372: Ulanowice pod Otmuchowem (QGNB, nr 351); 1375: Pielaszkowice k. Strzegomia (LKŚJ, I, nr 936); 1377 : Włodzienin k. Głubczyc (Lehns., II, s. 485); 1378: Morów pod Nysą (QGNB, nr 753); 1380: Kobiela k. Grodkowa (QGNB, nr 1109); 1381: Luboradzk. Jawora (LKŚJ, I, A 81); 1383: Wrocław-Gaj (RF, I, s. 166); 1385: Krzyżowa k. Świdnicy (LKŚJ, II, nr 79); 1386: Różana k. Złotoryi (LKŚJ, II, nr 306); 1386: Wiadrów k. Jawora (LKŚJ, II, nr 328); 1386: Rościszów (ob. cz. Pieszyc) k. Dzierżoniowa (LKŚJ, II, nr 973); 1391 i 1509: Godziszowa k. Jawora (LKŚJ, II, nr 919; Adamska 2005, s. 246); 1393: Bojanice k. Świdnicy (LKŚJ, II, nr 1150); 1393: Piotrowice Świdnickie /?/ (LKŚJ, II, nr 1223); 1393, 1396, 1407: Panków k. Świdnicy (LKŚJ, II, nr 1232; III, nr 576, 1728); 1396, 1480: Lutomia k. Dzierżoniowa (LKŚJ, III, nr 44; APWr., Rep. 39, nr 44, s. 33 ); 1396 i 1403: Kleczków ob. w granicach Świdnicy (LKŚJ, III, nr 258, A39); 1396 i 1407; Pietrzyków k. Bolko- 
w średniowieczu funkcjonowały dwa obiekty rezydencjonalne wymienione jako dwory [Hofe] w kilku dokumentach $z$ lat 1387-1391. W obu wypadkach identyfikować je możemy z reliktami murowanych wież mieszkalnych, jednak w świetle wstępnych ustaleń o nieco młodszej chronologii (LKŚJ, II, nr 401, 541, 973, 1019; Błoniewski 2017, 107-136). Można zatem przypuszczać, że wieże te to relikty młodszych faz zabudowy gródków stożkowatych, pierwotnie z lekką zabudową drewniano-glinianą. Również dwie siedziby pańskie funkcjonowały w Chichach koło Żagania, położone w dolnej i górnej części wsi, nazwane odpowiednio jako Niederhoffe (1431) i Obirhofe (1460). O dworze górnym niewiele wiadomo, natomiast dolny jest identyfikowany $\mathrm{z}$ datowanym na przełom $\mathrm{XV}$ i XVI w. regularnym założeniem z murem obwodowym i budynkiem mieszkalnym $\mathrm{w}$ jednym $\mathrm{z}$ naroży. Badania archeologiczne wykazały, że został on zbudowany na miejscu starszego obiektu drewniano-glinianego (RSL, nr 128, 257; Rozpędowski 1978, 510 511; Nowakowski 2008, 442-444).

wa (LKŚJ, III, nr 641, 1925, 1927); 1397, 1482, 1484, 1487, 1492: Rybnica k. Jeleniej Góry (LKŚJ, III, nr 269; APWr., Rep. 39, nr 44, s. 106, 263, 465, 735-736); 1399: Makowice k. Świdnicy (LKŚJ, III, nr 1073); 1399: Sędziszowa k. Świerzawy (LKŚJ, III, nr 507); 1402: Bukowiec k. Jeleniej Góry (LKŚJ, nr III, nr 1471); 1402: Domanice k. Świdnicy (LKŚJ, III, 1416); 1406: Prusice k. Jawora (LKŚJ, III, nr 1623); 1406: Żerków k. Lwówka (LKŚJ, III, nr 1693); 1407: Szymanów k. Strzegomia (LKŚJ, III, nr 1864); 1407: Warta Bolesławiecka (LKŚJ, nr III, 1885); 1429: Mirocin Dolny k. Kożuchowa (Inv. Grünb., s. 144); 1449: Ręków k. Sobótki (APWr., Akta m. Wrocławia, sygn. B 89.4, s. 20v); 1460: Wierzchowice k. Polkowic (Inv. Glog., s. 105); 1461: Raczkowa k. Legnicy (APWr., Akta m. Wrocławia, sygn. B 89. 4, s. 39v); 1469: Samborowice k. Ziębic (APWr., Akta m. Wrocławia, sygn. B 89. 4, s. 53v); 1474: Lubiechów k. Wałbrzycha (APWr., Dok. m. Świdnicy, nr 881 [U 959]); 1475: Piotrówek k. Niemczy (APWr., Akta m. Wrocławia, sygn. B 89. 4, s. 82v); 1477: Siedlęcin k. Jeleniej Góry (APWr., Rep. 39, nr 43, s. 86-87); 1484: Nieder Hoff w Pastuchowie k. Strzegomia (APWr., Rep. 39, nr 44, s. 254); 1489: Dzietrzychowice k. Żagania (RSL, nr 220); 1491: Lipa k. Jawora (APWr., Rep. 39, nr 44, s. 590); 1491: Sieniawka k. Dzierżoniowa (APWr., Rep. 39, nr 44, s. 590-591); 1491: Mściwojów k. Jawora (APWr., Rep. 39, nr 44, s. 613); 1491: Mirosławice k. Świdnicy (APWr., Rep. 39, nr 44, s. 618-619); 1492: Bolkowice k. Bolkowa (APWr., Rep. 39, nr 44, s. 718-719); 1493: Zabłocie k. Nowogrodźca (APWr., Rep. 39, nr 44, s. 855); 1494: Jeżów Sudecki k. Jeleniej Góry (APWr., Rep. 39, nr 44, s. 899); 1510: Mieczniki k. Niemczy (APWr., Akta m. Wrocławia, sygn. B 89. 4, s. 181).
Przykładem większych rozmiarów rezydencji jest również wzmiankowany w 1369 r. dwór [hofe] z Łażan koło Świdnicy. W obrębie tamtejszego pałacu zachowały się relikty kamiennego założenia z XIV w. Jego głównym elementem był długi dom, który stał we wschodniej części dziedzińca opasanego murem obwodowym o czworobocznym zarysie (LKŚJ, I, nr 351; Błoniewski 2017, 169-180). Jak się uważa wymieniony w 1376 r. dwór w Gościszowie [niedersten hof] zbudowano na miejscu starszego założenia, którego kształt powielać ma owalny zarys murów obwodowych (ryc. 2:a). Przy zachodnim odcinku muru zbudowano niewielką, podpiwniczoną wieżę mieszkalną (LKŚJ, I, nr 1126; Chorowska 2003, 142-143; Eysymontt 2010, 266-267). Z kolei w Borowie Polskim koło Kożuchowa poświadczony w 1484 r. dwór [Hofe] wzniesiono na przełomie XIV i XV w. Było to relatywnie duże, dwuskrzydłowe założenie $\mathrm{z}$ murem obwodowym i fosą (ryc. 2:b). Również tutaj pod nasypem dziedzińca odsłonięto relikty starszej zabudowy drewniano-glinianej, być może pozostałości wzmiankowanego już w 1295 r. folwarku należącego do kasztelana kożuchowskiego Dytryka de Pesna (SUb, VI, nr 196, 202; Inv. Grünb., 79; Nowakowski 2008, 426).

Późne przykłady wzmianek o dworach rycerskich odnajdujemy w landbuchu opolsko-raciborskim. W 1524 r. Mikołaj Klema z Ligoty otrzymał za wierne służby dwor w Starej Wsi koło Raciborza (obecnie ul. Starowiejska). Dwa lata później analogicznie określony obiekt poświadczony był w niedalekiej Studziennej (obecnie płd. część Raciborza) (LOR, nr 54, 105). Niestety, prawdopodobnie oba zostały całkowicie zniszczone współczesną zabudową.

\section{Curia habitationis}

Mieszkalny charakter średniowiecznych dworów potwierdza źródłowy termin curia habitationis/ Wohnhof. Jeden ze starszych przykładów jego użycia [1341,1348] odnosi się do obiektu zbudowanego przez biskupa wrocławskiego w Białej koło Otmuchowa. Niestety, w późniejszym czasie został on zniszczony, można jednak przypuszczać, że było to niewielkie założenie. Położony niedaleko od głównych zamków w Otmuchowie i Nysie dwór zapewne pełnił funkcję podmiejskiej rezydencji wrocławskiego ordynariusza (SR 6574b; SR 6574b; QGNB, nr 11; Legut-Pintal 2017, 160-161). 

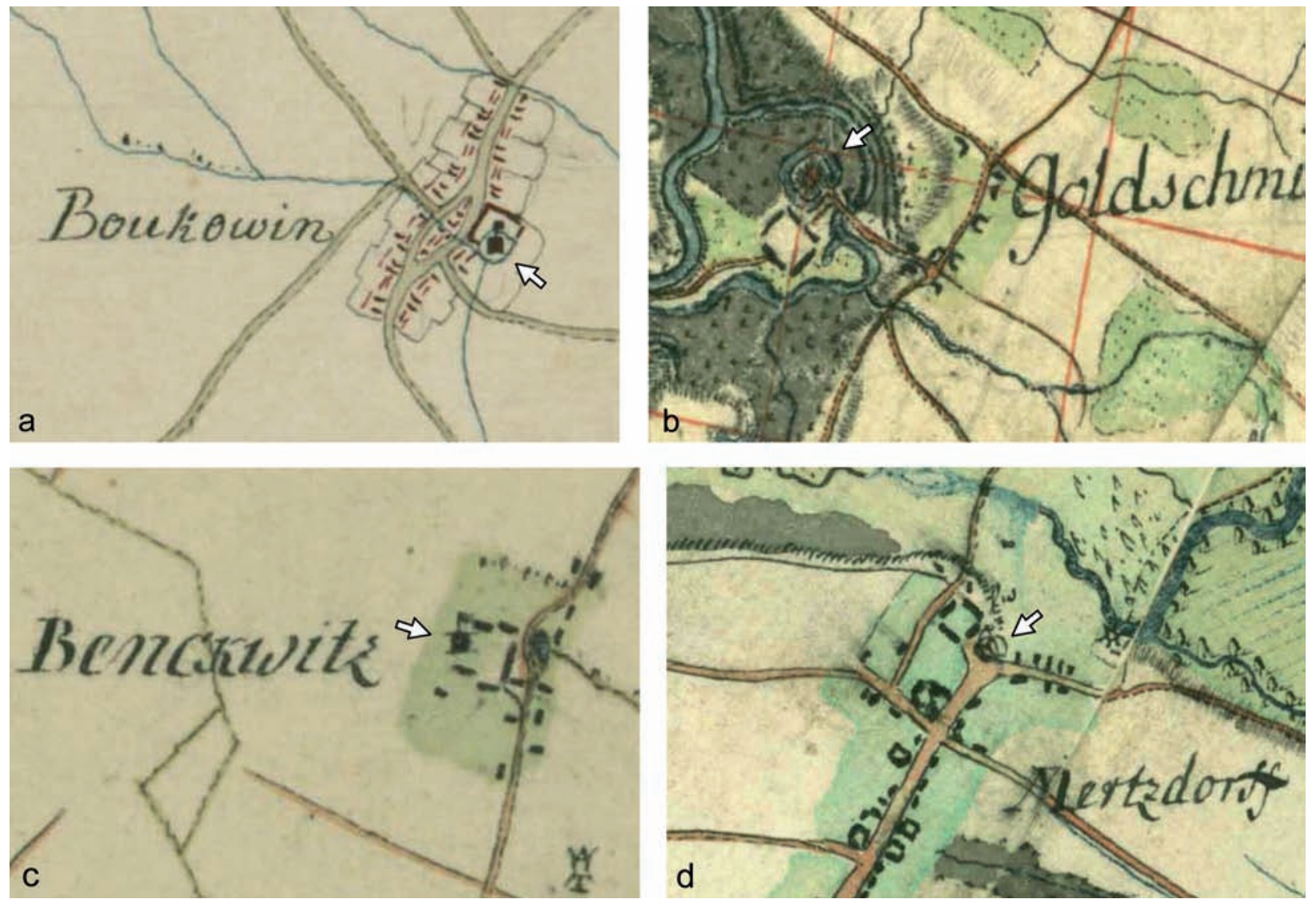

Ryc. 1. Plany wsi z lokalizacją obiektów obronno-rezydencjonalnych wg XVIII-wiecznych map Ch.F. Wredego (a) i L.W. Reglera (b-d): a) Bukowina; b) Złotniki; c) Bieńkowice; d) Marcinkowice (Staatsbibliothek Berlin, Preußischer Kulturbesitz, sygn. N 1506, N 15140)

Fig. 1. Plans of the village with the location of defense and residential objects according to the 18th-century maps of Ch.F. Wrede (a) and L.W. Regler (b-d): a) Bukowina; b) Złotniki; c) Bieńkowice; d) Marcinkowice (Staatsbibliothek Berlin, Preußischer Kulturbesitz, sign. N 1506, N 15140)

W 2. poł. XIV w. określenie curia habitationis było często używane w kancelarii księstwa legnickobrzeskiego. Przez wydawcę regestów dokumentów księcia Ludwika I brzeskiego było tłumaczone jako Haus, Wohnung i Wohnhaus ${ }^{6}$. Przykładem może być

6 1358: Zabardowice k. Oławy (UHLB, nr 97); 1358: Gaj Oławski k. Oławy (UHLB, nr 119); 1361 i 1362: Siecieborowice k. Oławy (UHLB, nr 327, 330, 432); 1361: Studnica k. Chojnowa (UHLB, nr 348, 356); 1362: Kuny k. Oławy (UHLB, nr 401); 1362: Okmiany k. Chojnowa (UHLB, nr 408); 1362: Schöneiche (ob. część Wyszonowic) k. Strzelina (UHLB, nr 419); Miłonów k. Oławy (UHLB, nr 421); Godziszów k. Oławy (UHLB, nr 425); 1362: Drzemlikowice k. Oławy (UHLB, nr 451); 1362: Mumochowicz (ob. część Kucharzowic) k. Wiązowa (UHLB, nr 456); 1362 i 1366: zaginione Ketzerfeld k. Lubina (UHLB, nr 433, 630; SWŚ, I, s. 104-105); 1363 i 1366: Koźlice k. Lubina (SWŚ, I, s. 112); 1363: Kurów k. Wiązowa (UHLB, nr 504); 1364: Brzezina k. Brzegu (UHLB, nr 515); 1364: Kucharzowi- poświadczony w 1360 r. dwór mieszkalny z Czerńca pod Lubinem. Obiekt ten identyfikować należy ze znanymi z archiwaliów reliktami grodziska stożkowatego otoczonego fosą, położonymi przy wschodnim krańcu wsi (SWŚ, I, 83; Nowakowski 2008, 454455 , ryc. 142). W źródłach sporadycznie spotykamy także nieco inne zapisy, czego przykładem może być wzmiankowany w 1362 r. obiekt z Siedlec koło Oławy, określony jako stary dwór mieszkalny [antiqua curia mansionis] (APWr., Rep. 21, sygn. 1A, 116; UHLB, nr 463). Aż trzykrotnie w dokumentach wymieniono obiekt w Rynarcicach koło Lubina, kolejno jako curia

ce k. Wiązowa (UHLB, nr 528); 1365: Krzeczyn Wielki k. Lubina (UHLB, nr 590; SWŚ, I, s. 114-115); 1366: Osiek k. Lubina (UHLB, nr 632; SWŚ, I, s. 140); 1385: Sulisławice k. Ząbkowic Śląskich (APWr., Rep. 102, nr 69); 1393: Paruszowice k. Oławy (UHLB, nr 1099); 1409: Skałągi k. Wołczyna (Haeusler 1883, s. 436). 

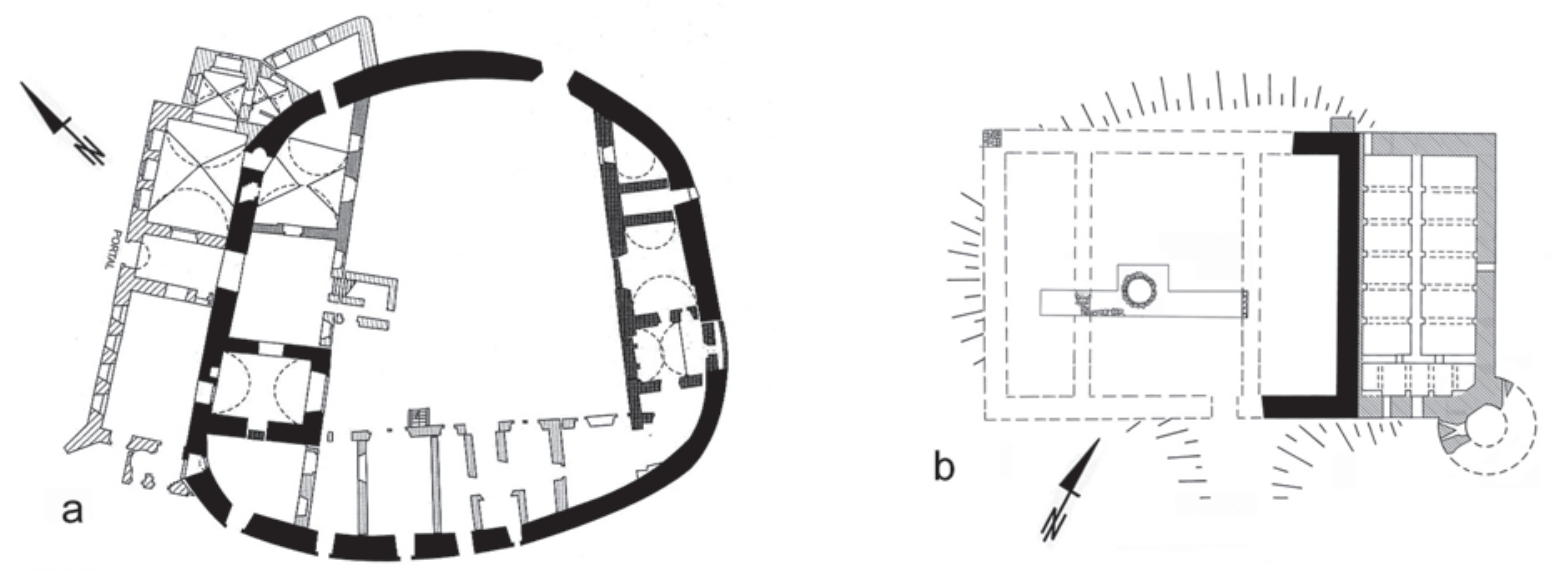

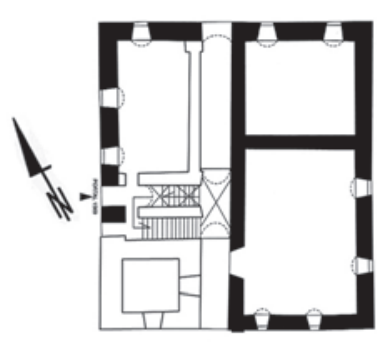

C

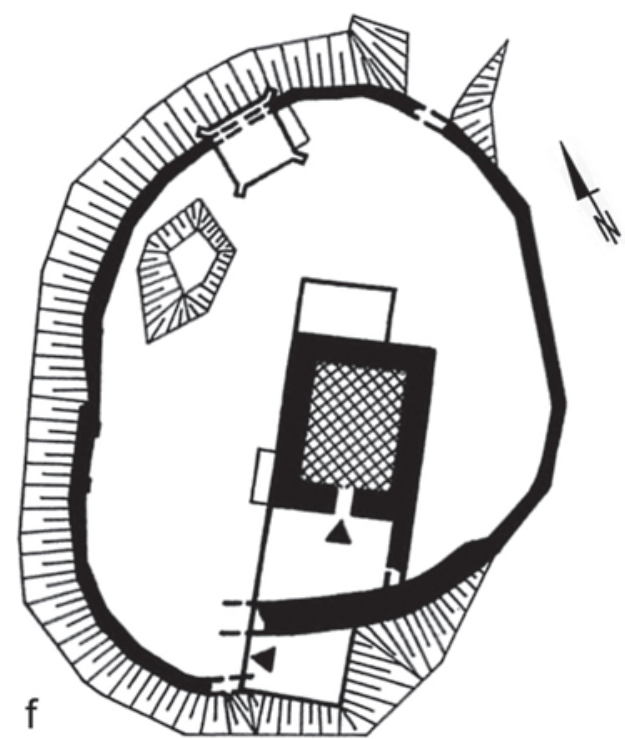

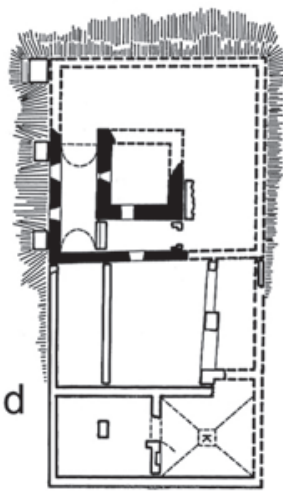
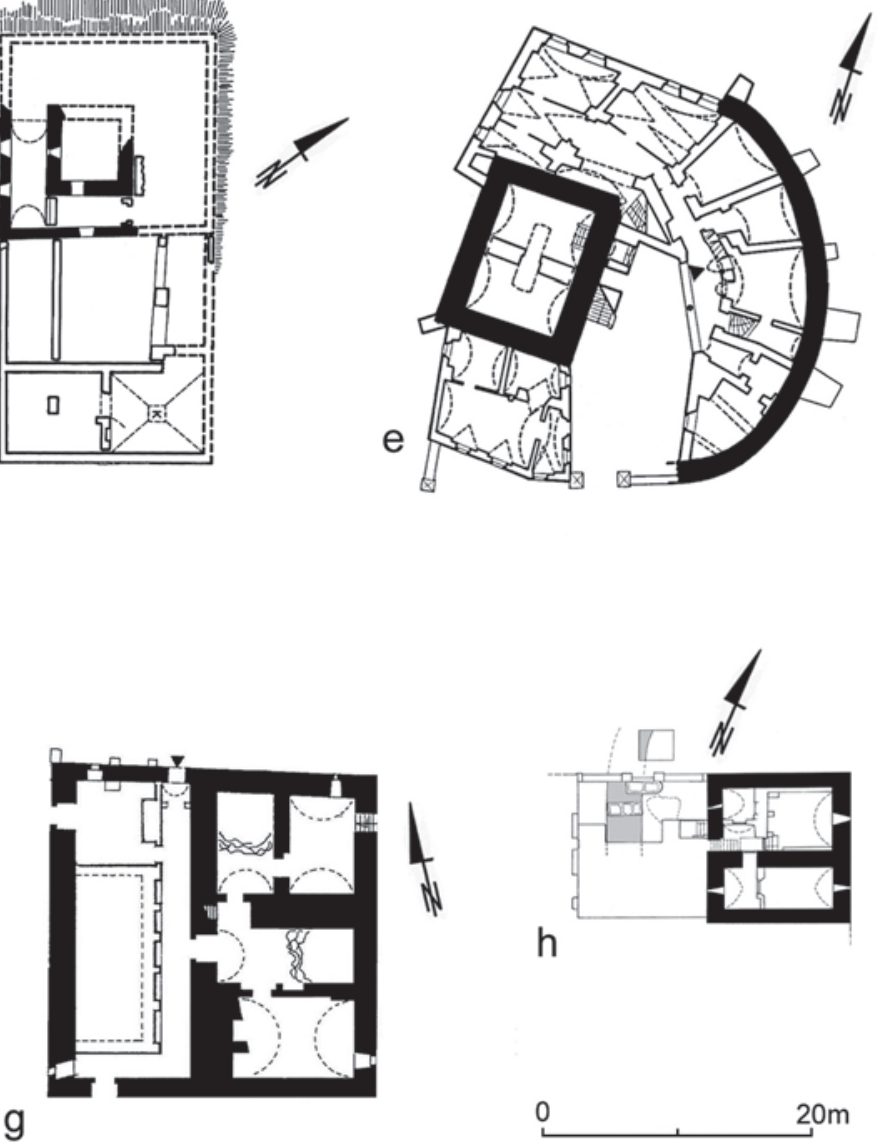

Ryc. 2. Plany dworów i zamków na poziomie piwnic z zaznaczoną najstarszą fazą zabudowy: a) Gościszów (za: Eysymontt 2010); b) Borów Polski (za: Nowakowski 2008); c) Gniewków (za: Eysymontt 2010, opr. autor); d) Kłaczyna (za: Chorowska 2003); e) Ciepłowody (za: Chorowska 2003); f) Jędrzychów (za: Chorowska 2003); g) Siedlisko (za: Kąsinowska 2003); h) Wierzbna (za: Boguszewicz 2005)

Fig. 2. Plans of manor houses and castles at the basement level marked with the oldest building phase: a) Gościszów (after: Eysymontt 2010); b) Borów Polski (after: Nowakowski 2008); c) Gniewków (after: Eysymontt 2010);

d) Kłaczyna (after: Chorowska 2003); e) Ciepłowody (after: Chorowska 2003); f) Jędrzychów (after: Chorowska 2003); g) Siedlisko (after: Kąsinowska 2003); h) Wierzbna (after: Boguszewicz 2005). 
habitationis (1359), curia habitationis et suis edificis (1360) i curia prope habitacionem (1365). Uwage zwraca ostatnie określenie, albowiem poprzez użycie przyimka prope pisarz wyraźnie oddzielił dwór od części mieszkalnej. $Z$ danych archiwalnych wiadomo, że we wsi znajdowało się dwuczłonowe założenie obronno-rezydencjonalne, którego głównymi elementami były das Große und das Kleine Wall (SWŚ, I, 157-160; Nowakowski 2008, 532-533). Podobne określenie odnajdujemy też w spisanym w języku niemieckim dokumencie z 1362 r., potwierdzającym nabycie przez Peczko von Schellendorfa w Witkowie koło Chojnowa folwarku mit der Hofe der Wonunge (APWr., Rep. 21, sygn. 1A, 98; UHLB, nr 394).

Często termin curia występuje $\mathrm{w}$ źródłach $\mathrm{z}$ dodatkowymi określeniami, które umożliwiają nieco bliższą charakterystykę interesujących nas założeń. W księgach rezygnacji księstw świdnickiego i jaworskiego odnajdujemy liczne dane o dworach murowanych [curia murata, gemauerte Hof] ${ }^{7}$. Terminów tych używano przede wszystkim w odniesieniu do obiektów mieszkalnych, a przeprowadzone $\mathrm{w}$ ostatnich latach badania architektoniczne Piotra Błoniewskiego wykazały, że ich relikty kryją ruiny nowożytnych pałaców.

Już w 1336 r. curia murata była poświadczona w Pieszycach koło Dzierżoniowa. Niestety, obiekt ten nie został, jak dotąd, zidentyfikowany w terenie, a wokół jego lokalizacji trwają spekulacje. Część badaczy sugeruje, że mógł być on położony w sąsiedztwie kościoła, gdzieś w okolicy obecnego barokowego pałacu (RS, nr 5575; Adamska 2005, 124; Boguszewicz 2010a, 140). Wymieniony w 1370 r. gemauerten hof w Gniewkowie koło Jawora można powiązać z datowanym na XIV w. założeniem o regularnym czworobocznym planie, z murem obwodowym i domem mieszkalnym przylegającym do jego wschodniej kurtyny (ryc. 2:c) (LKŚJ, I, nr 405; Eysymontt 2010, 261, Błoniewski 2017, 83-91). Wzmiankowany w 1403 r. vorwerk mit dem gemawirten hofe w Wierzbnej koło Świdnicy, własność rodziny von Rohnau, łączy się z reliktami kamiennej wieży mieszkalnej (ryc. 2:h), odkrytej w obrębie położonego przy kościele nowożytnego pałacu opata (LKŚJ, III, nr 1490; Chorowska 2003, 150-151; Boguszewicz 2005, 292-296). W Kła-

7 1375: Kupferberg w Janowicach Wielkich k. Jeleniej Góry (LKŚJ, I, nr 1021); 1403 i 1407: Bolków Zdrój obecnie część miasta Bolkowa (LKŚJ, III, nr 1465; APWr. Rep. 39 nr 39, s. 10); 1410: Bielawa k. Dzierżoniowa (APWr. Rep. 39 nr 39, s. 335-336) czynie koło Bolkowa zachowane są relikty niewielkiej wieży mieszkalnej otoczonej czworobocznym murem kurtynowych i mokrą fosą (ryc. 2:d). Obronny charakter obiektu został podkreślony w dokumencie z 1368 r., w którym Rule Beyer zapisał swojej żonie curiam muratam exceptam usque ad fossam (LKŚJ, I, nr 262; Chorowska 2003, 171).

Na tle wyżej wymienionych przykładów w sposób wyjątkowy określono wieżę w Pastuchowie koło Strzegomia. Pierwotnie położona była na terenie folwarku górnego, który w 1389 r. został sprzedany mit dem steynwerke. W kolejnych dwóch przekazach z 1402 r. obiekt ten wymieniony był jako das Obirste gut mit dem steynnenthurme (LKŚJ, II, nr 509, 613; III, nr 1164, 1167). Wiemy również, że dwór [curia] z murowanym domem (wg regestu mit dem gemauertem Haus), położony w Piotrowicach koło Nysy, w 1368 r. Jan Pogorzela sprzedał Mikołajowi z Ciepłowodów. Rok później krewni Mikołaja zrzekli się praw do tego obiektu, określonego w dokumencie jako castrum. Niestety, nie wiemy, jak wyglądało założenie najstarsze. W murach nowożytnego pałacu odkryto relikty obiektu z XV w., najpewniej dwuskrzydłowego dworu z murem obwodowym, z długim budynkiem we wschodniej części dziedzińca i drugim budynkiem w części zachodniej (QGNB, nr 68, 125; Legut-Pintal 2017, 159-160). Z kolei w Luboradzu koło Jawora w 1408 r. Mikołaj Sachenkirche „od dawna posiadał” dobra we wsi, w tym dwór z folwarkiem i wszystkimi zabudowaniami murowanymi i drewnianymi [hofe und dem vorwerke mit allen gebewden steinwerke und holczwerke] (APWr., Rep. 39, nr 39, 87). Przykładem niewielkiego założenia typu motte z elementami zabudowy murowanej może zaś być obiekt $\mathrm{z}$ niedalekich Imbramowic, poświadczony w 1399 i 1406 r., kolejno jako hofe i gemauerten hof (LKŚJ, III, nr 498, 1638; Błoniewski 2017, 102-108).

\section{Gesesse}

Opisane powyżej przykłady Rynarcic i Witkowa pokazują, że w śląskich dokumentach od 3. ćwierci XIV w. pojawia się rozróżnienie gospodarczego dworu od właściwej siedziby mieszkalnej, coraz częściej określanej jako Gesesse. W kontekście rozważań nad tym terminem interesujący jest przykład wsi Ujeździec koło Paczkowa. Jej nazwę w dokumentach z końca XIII w. konsekwentnie zapisywano jako Vyeszez. Po raz pierwszy pod nazwą Gezëse pojawiła się w księdze uposażenia biskupstwa wrocławskiego i w kilku 
dokumentach z pierwszej połowy XIV w., w tym falsyfikacie opatrzonym datą 1291 r. (SUb, VI, nr 70, 271, 462; Lf, A, 220). W 1354 r. biskup Przecław odstąpił Bolkowi II świdnicko-jaworskiemu wieś i zamek Geseze, w ramach rekompensaty za udzieloną pomoc. Jako Gesese osada wielokrotnie była wzmiankowana w nyskim lagerbuchu. Wówczas tamtejsze dobra należały już do rodziny von Dohna, przy czym w 1375 r. Jan Dohna sprzedał połowę młyna, dwór [curia] i połowę folwarku we wsi. Nową nazwę wsi (Gesese) można zaliczyć do znanych ze Śląska przykładów toponimów utworzonych od siedziby pańskiej. W tym wypadku dwór biskupi zbudowany został zapewne około przełomu XIII i XIV w. Zmianie nazwy wsi mogła także towarzyszyć strukturalna i prawna reorganizacja samego osiedla. Jeszcze 1444 r. miejscowość Gesese wymieniono wśród zamków [slöszir] księstwa nyskiego. (APWr., Rep. 31, sygn. 2A, s. 77v; Rś, II, nr 1007; QGNB, nr 618, 619; Lehns., II, 263; Legut-Pintal 2017, 158-159).

Wspomniane wyżej rozróżnienie gospodarczego dworu i siedziby mieszkalnej, manifestowało się często spotykanym w źródłach zestawieniu Hofe und Gesesse. W taki sposób w 1369 r. zapisana została siedziba w Łażanach koło Strzegomia, którą po ojcu odziedziczyli bracia Gunczel i Themlin von Lazan. Identyfikować ją należy zapewne z reliktami kamiennego założenia z XIV w., zachowanymi w obrębie tamtejszego nowożytnego pałacu. Głównym elementem średniowiecznej siedziby był długi dom, który stał we wschodniej części dziedzińca opasanego murem obwodowym o czworobocznym zarysie (LKŚJ, I, nr 351; Błoniewski 2017, 169-180). Interesującym przykładem wzajemnej relacji siedziby pańskiej i dworu jest obiekt z Wierzbic koło Wrocławia. Liczące 10 łanów allodium z wieżą [cum turri] wymieniono już w 1346 r., natomiast w 1373 r. obiekt ten, wówczas własność mieszczanina wrocławskiego Jana Dompniga, określono jako Thurm und Hof (RF, IV, 2942, 2943). Potomkowie Jana, bracia Zenke i Franciszek, w 1410 r. sprzedali Wacławowi Schwarz swój folwark mit dem Gesäß oder Hoff mit dem Thurm. Z treści zapisu wynika zatem, że niekiedy określenie Gesesse mogło być używane jako synonim dworu. Nieco inną wymowę ma dokument z 1423 r., kiedy wspomniany Wacław sprzedał mieszczaninowi Mikołajowi Stolz cały folwark w Wierzbicy mit dem Thurme, Gesäß und Hoff. Ponownie siedziba, dwór i wieża [Gesäß, Hof und Thurm] wymienione były w 1514 r. (RF, III, $321,322,324)$. Nie można wykluczyć, że złożony opis siedziby z Wierzbic, to w tym wypadku rodzaj zabie- gu kancelaryjnego, mającego wyrazić jedynie to, że przedmiotem sprzedaży były wszystkie wchodzące w jej skład nieruchomości. Obiekt ten identyfikować można z reliktami grodziska stożkowatego położonymi na terenie wsi Krzyżowice (pierwotnie Klein Wirbitz, a następnie Schlanz) (Nowakowski 2017a, 342-343).

W 1375 r. dwór z siedzibą [hofe und gesezze] potwierdzono w Przerzeczynie koło Niemczy. Również tutaj, do niedawna w północnej części wsi, w parku dawnego majątku, było zachowane bliżej nierozpoznane grodzisko stożkowate. Otwarta pozostaje kwestia fundatorów tego założenia. Od 1. poł. XIII w. wieś stanowiła własność siedzącej tam rodziny Jeleńczyków. Osadę na prawo niemieckie przeniósł najpewniej Dzierżko, stąd jej późniejsza nazwa Dirsdorf, natomiast od połowy XIV w. tamtejsze dobra należały do Niemandsów (LKŚJ, I, nr A31; Nowakowski 2017a, 399).

Starosta Benesz z Choustník w 1386 r. sprzedał Elżbiecie von Parchwitz wszystkie swoje dobra dziedziczne w Maniowie Małym, w tym den hof und daz gesesse doselbist. Obiekt ten identyfikować możemy z dużym założeniem typu motte o czworobocznym planie, z dookolną fosą i z zewnętrznym wałem (LKŚS, II, nr 400; Nowakowski 2017a, 357-358). W tym samym roku w Siedlimowicach koło Strzegomia wymieniono den hof und daz gesesse mit dem vorwerke. W obrębie tamtejszego nowożytnego dworu odkryto relikty założenia z XIV w., którego elementem była niewielka kamienna wieża mieszkalna (LKŚJ, II, nr 235; Błoniewski 2017, 234-245). Aż czterokrotnie jako Gesesse $(1388,1399,1401,1403)$ zapisano siedzibę z Kunic, wsi znajdującej się obecnie w granicach Jeleniej Góry (LKŚJ, II, nr 535; III, nr 551, 1050, 1529). Być może relikty tego obiektu kryją się pod pałacem z XIX w., zbudowanym na wyraźnie eksponowanym cyplu wcinającym się w dolinę Bobru.

W świetle zebranych materiałów określenia Gesesse $^{8}$ oraz Hofe und Gesesse $e^{9}$ coraz częściej wystę-

8 1399: Gola k. Dzierżoniowa (LKŚJ, III, nr 666, 667); 1400: Mrozów k. Środy Śląskiej (RF, II, s. 834); 1400 i 1405: Chomiąża k. Środy Śląskiej (RF, II, s. 571, 574); 1402: Parzyce k. Nowogrodźca (LKŚJ, III, nr 1507); 1405 i 1425: Chwalimierz k. Środy Śląskiej (RF, I, s. 130); 1454: Krępice k. Środy Śląskiej (RF, I, s. 506); 1444: Złotniki k. Wrocławia (RF, I, s. 191); 1532: Orzegów k. Bytomia (APWr., Rep. 4f, sygn. 151, s. 260v).

9 1397: Jaźwina k. Dzierżoniowa (LKŚJ, III, nr 1289); 1401: Dobrocin k. Dzierżoniowa (LKŚJ, III, nr 934); 1401: Śmiałowice k. Świdnicy (LKŚJ, III, nr 1053); 1402: Gnie- 
powały w zapisach z przełomu XIV i XV w. i były używane jeszcze w początkach XVI w. Niektóre z nich, podobnie jak wcześniej opisane przykłady, identyfikować możemy z grodziskami stożkowatymi. Z położonej na południe od Wrocławia Ślęzy-Lasowa znamy natomiast przykład bardzo dobrze zachowanej ceglanej wieży mieszkalnej z XIV-XV w. Obiekt ten należał do różnych rodzin mieszczan wrocławskich i jako Hofe und Gesäße odnotowano go w 1410 i 1470 r. (RF, I, 211; Degen 1965, 161-163, ryc. 69; Chorowska 2003, 147). Najpewniej większe założenie funkcjonowało w obecnie nieistniejącym folwarku Sternaw w okręgu bolesławieckim. Tu w 1482 r. znajdował się murowany dwór z siedzibą [gemawerte hoffe und gessässe] (APWr., Rep. 39, nr 44, 114-115). Obiekt ten należy identyfikować z przedstawioną na archiwalnych mapach budowlą opisaną jako Sternmauer, na zachód od północnego krańca tej wsi. Na skaningu laserowym tego obszaru widoczny jest okazały kopiec położony w dolinie niewielkiego cieku.

\section{Area habitationis}

Niezwykle interesujące, choć niestety rzadko spotykane w źródłach, są określenia placów pod budowę dworów mieszkalnych. W Pieszkowie pod Lubinem w 1360 r. Henryk de Sar sprzedał braciom von Redern czynsz na różnych dobrach we wsi cum duabus areas pro curiis habitatiorum ibidem edificaris. Wydaje się, że sprzedane zostały wówczas dwie niezabudowane parcele, choć nie można wykluczyć, że teren pod budowę dworów został wcześniej w jakiś sposób przygotowany. Niestety z Pieszkowa, jak dotąd, nie znamy żadnych reliktów siedzib pańskich (SWŚ, I, 146). Dwa lata później Jadwiga, wdowa po Janie von Slewitz, sprzedała jeden z czterech łanów jakie posiadała w Lizawicach koło Oławy, z czwartą częścią area habitationis, co autor regestu przetłumaczył jako Hoferaum (UHLB, nr 476). Analogicznie został określony grunt jaki w całości, wraz 2 i 1 1 ła łanu, sprzedała Agata, wdowa po Mikołaju von Poschwitz w Jędrzychowicach koło Wiązowa (UHLB, nr 484).

chowice k. Wrocławia (RF, I, s. 179); 1403 i 1422: Samotwór k. Wrocławia (RF, III, s. 2134-2135); 1407: Rościszów (ob. cz. Pieszyc) k. Dzierżoniowa (APWr., Rep. 39, nr 39, s. 19); 1409: Luboradz k. Jawora (APWr. Rep. 39, nr 39, s. 240); 1410, 1423, 1514: Krzyżowice k. Wrocławia (RF, III, s. 321, 324); 1425 i 1467: Skałka k. Wrocławia (RF, III, s. 310-311); 1498: Małkowice k. Wrocławia (RF, II, s. 726).
W obu sytuacjach wyzbywanie się majątków przez wdowy może być świadectwem ich nienajlepszej kondycji finansowej. Majętni nie byli też rycerze z położonych między Wrocławiem a Oławą Groblic. W 1368 r. Lutko de Grobilwicz sprzedał braciom Zbylutowi i Pakuszowi 2 łany we wsi i ogród przeznaczony na budowę domu mieszkalnego [et 1 ortum pro habitatione facienda]. Sześć lat później wyzbył się kolejnego łanu, z połową dworu z zabudowaniami [cum 1/2 parte curiae cum aedificis] (APWr., Rep. 66, nr 224, 256, 260; UHLB, nr 669, 770, 781). Podobną wymowę mają zapisy dotyczące wsi Jeszkowice koło Wrocławia. Siedzący tam bracia Strachotowie w 1405 r. dokonali podziału dóbr tak, że czterech z nich otrzymało 4 łany i ungebawten Hof, a dwaj pozostali 2 łany i gebauten Hof (RF, I, 397). Najstarszy $\mathrm{z}$ braci wystąpił jako töchtige Andreas von Strachota, co sugeruje, że byli to drobni rycerze, których pozycja majątkowa - po dokonanym podziale - była równa kmieciom. Przy omawianiu sprawy placów pod budowę dworów oraz ich lokalizacji w obrębie siedlisk wsi, należy przywołać sugestywny przykład drugiego obiektu z Czerńca koło Lubina. Niestety, tylko z danych archiwalnych z końca XIX w. wiadomo, że był on położony w centrum wsi, niedaleko od drogi, za budynkiem ówczesnego inspektora, na terenie zwanym Prittwitzgarten. Najpewniej pierwotnie założenie stało za szeregiem zabudowy wiejskiej, a więc w miejscu, gdzie zwykle znajdowały się ogrody. Tradycyjna nazwa gruntu sugeruje, że obiekt ten identyfikować można jako dwór Prittwitzów, którzy siedzieli w Czerńcu w XV-XVI w. Ich pierwszy udokumentowany przedstawiciel - Albert Prittwitz - w $1423 \mathrm{r}$. miał liczne dobra we wsi, w tym obiekt mieszkalny, zapisany jako hewsern der wonungen (SWŚ, I, 84).

\section{Curia allodii - Vorwerk}

Już w kilku wcześniej przywoływanych dokumentach dostrzec można wyraźny związek siedzib pańskich z folwarkami. Pojęcie allodium oznaczało w średniowieczu przede wszystkim majątek ziemski i w tym sensie stanowiło synonim późniejszego folwarku, niekiedy określanego też jako curia (Stownik taciny..., I, 422-424; Deutsches Wörterbuch..., XXVI, 1927-1934). Godny uwagi jest przykład sprzedanego w 1369 r. folwarku ze Stabłowic (obecnie osiedle w północno-zachodniej części Wrocławia). Wśród licznych nieruchomości wchodzących w jego skład wymieniono zarośla [Pusche], które leżały hinter dem 
Hofe des Fuhrwergks (RF, IV, 2672-2673). Można zatem przypuszczać, że w tym wypadku dworem nazwano zabudowania folwarczne. Warto podkreślić, że w literaturze zwracano już uwagę na obronny charakter zabudowań gospodarczych, w tym folwarcznych, położonych przy siedzibie pańskiej. Często założenie takie tworzył zwarty blok budynków spiętych wspólnym obwodem, z jednym wjazdem, który niekiedy miał formę wieży bramnej (Kašička 1985). Niestety, na Śląsku wzajemne relacje siedzib pańskich i położonych w ich sąsiedztwie dworów-folwarków są bardzo słabo rozpoznane archeologicznie. Niemniej jednak zaobserwowano, że relikty średniowiecznych obiektów obronno-rezydencjonalnych bardzo często położone są $\mathrm{w}$ sąsiedztwie zabudowań nowożytnych folwarków (Nowakowski 2008, 243-244). Wobec powyższych uwag bardzo interesujące wydają się określenia odnoszące się do dworu w Jarząbkowicach (Gorsebkowitz/Schriegwitz) koło Wrocławia. W 1353 r. rycerze Paszko de Grzebkowiz i Jan von Borschnitz sprzedali mieszczaninowi wrocławskiemu allodium Gorsebkowicz cum curia allodii. Dwa lata później przedmiotem sprzedaży była wieś i położone na jej terenie allodium et curia. $\mathrm{Z}$ danych archiwalnych wiadomo, że w tej niewielkiej wsi folwarcznej znajdowały się bliżej nierozpoznane relikty obiektu typu motte. Nie sposób rozstrzygnąć, czy miał on jakiś związek z wzmiankowanym w źródłach pisanych dworem $z$ folwarkiem (RF, I, 215; Nowakowski 2017a, 314).

W Wieśnicy koło Strzegomia rycerz Sander w 1319 r. zapisał cystersom z Krzeszowa położone we wsi Gute oder Hofe. Z dokumentu jednoznacznie wynika, że oba terminy traktowano synonimicznie, a użyty zwrot rozumiano zapewne jako folwark. Również tutaj znane $\mathrm{z}$ danych archiwalnych relikty grodziska stożkowatego lokalizowano w sąsiedztwie zabudowań folwarcznych (SR 3892, 3893; Nowakowski 2017a, 81, 458). O mieszkalnej funkcji folwarków świadczyć może przykład wsi Wysoka koło Wrocławia. W 1332 r. wrocławska kapituła katedralna sprzedała tamtejsze allodium mieszczaninowi Janowi von Nosin, który pięć lat później kupił od Jan Luksemburskiego przypisane do folwarku prawo stacji. Kwestią otwartą pozostaje, czy przedmiotem sprzedaży był wówczas już tylko podatek, czy też faktycznie przy folwarku znajdował jakiś budynek mieszkalny i czy ewentualnie jego pozostałościami jest położone na południe od zabudowań folwarcznych grodziska stożkowatego (SR 5144; 5863; Nowakowski 2017a, 467).
Z wsią Brochocin koło Chojnowa wiąże się przekaz jednoznacznie potwierdzający mieszkalny charakter folwarku. Siedzący tam Jerzy Budziwoj w 1486 r. sprzedał Krzysztofowi Ruprechtowi swoje posiadłości, z wyłączeniem folwarku, w którym mieszkał [ausgeczohgen das Forwergk, darauff der genandte George Buswe wohnet] (APWr., Rep. 39, nr 44, 366-367). W przypadku podobnych transakcji w dokumentach zwykle wymieniano położone przy folwarkach siedziby pańskie. Przykładem może być położony koło Jeleniej Góry Podgórzyn. W 1491 r. Wilrich von Liebenthal sprzedał swoje dobra we wsi, w tym folwark i dom mieszkalny [Forwergk und dem Wonhaus] (APWr., Rep. 39, nr 44, 560-563). Być może zatem w opisanym wcześniej Brochocinie dom mieszkalny nie był wolnostojącym budynkiem, lecz zajmował miejsce w ciągu zabudowań folwarcznych.

W kontekście rozważań nad wzajemną relacją siedzib pańskich i folwarków niezwykle interesujące są przykłady dwóch zaginionych czternastowiecznych folwarków Katzenschinder i Egilsjagt, położonych w sąsiedztwie wsi Buczki i Cesarzowice koło Środy Śląskiej. Bezprecedensowy charakter ma przekaz związany z pierwszym z nich. Wiemy, że w $1340 \mathrm{r}$. sołtys wsi Buczki przekazał żonie folwark [allodium] zwany Katzenschinder z mostem zwodzonym [cum ponte fortalicii, qui vulgo czogebrucke nuncupatur]. $\mathrm{Z}$ kolei folwark Egilsjagt wymieniony był w kilku dokumentach z 2. poł XIV-XV w. (RS, nr 6514; RF, I, 69a, 70b, 438, IV, 3046, 3050, 3077). Oba identyfikować należy z reliktami dwóch obiektów obronno-rezydencjonalnych, położonymi w kompleksie leśnym między wsiami Buczki, Cesarzowice i Ciechów. W archiwaliach i starszej literaturze opisano je jako grodziska stożkowate z Ciechowa lub Chwalimierza. Skaning laserowy terenu oraz badania powierzchniowe wykazały, że pod względem formalnym odbiegają one znacznie od klasycznych założeń typu motte z ziemnym kopcem otoczonym fosą i niekiedy przylegającym do niego podzamczem. Lepiej zachowane założenie, zlokalizowane na południowy wschód od wsi Buczki, tworzą dwa rozległe place otoczone rowami o wymiarach zewnętrznych ok. 93 × 74 i 30 × 75 m, $\mathrm{z}$ niewielkim kopcem otoczonym fosą $\mathrm{w}$ narożniku większego z nich. Drugi obiekt, położony niecały kilometr na północny wschód, składa się z dwóch mniej więcej tej samej wielkości czworobocznych członów o całkowitych wymiarach zewnętrznych ok. 75 x 120 m. Przed zniszczeniem, jeden z nich zajmował okazały kopiec (Nowakowski 2017b, 226-229). 


\section{Castrum, castellum}

Dla badaczy zajmujących się problematyką średniowiecznych obiektów obronno-rezydencjonalnych szczególną wartość mają przekazy potwierdzające ich warowny charakter. Określeniami powszechnie łączonymi z tego typu założeniami, w tym interesującymi nas niewielkimi siedzibami pańskimi są castrum/ Burg, fortalicium/Veste/Feste, Hus/Haus. Stosowano je przeważnie w odniesieniu do obiektów książęcych i biskupich, zwykle większych od założeń identyfikowanych jako fundacje rycerzy, mieszczan i sołtysów. Podobnie jak curia, także termin castrum/Burg był w średniowieczu pojęciem o bardzo szerokim znaczeniu, wykorzystywanym dla określenia różnego rodzaju obiektów ufortyfikowanych. We wczesnym średniowieczu castrum oznaczało przede wszystkim gród, natomiast później najczęściej murowany zamek (Stownik taciny..., II, 234-235; Kunstmann 1967, 1-7; Dobrzański 1978). Od końca XIII w. wymieniane w przekazach castra identyfikować możemy także z założeniami typu motte, jak np. Lubrza [1304, 1330] i Wityń [1304] koło Świebodzina (KDW, II, nr 880, 888, 1106), Tarnów Jezierny koło Głogowa [1331, 1360] (Lehns., I, 133, 178), Borucin koło Raciborza [1373] (RSW, nr 51), Domaradz koło Namysłowa [1396] (Lehns. II, 318). Niektóre obiekty pojawiały się w źródłach wielokrotnie, niekiedy w odstępie kilkudziesięciu lat, a stosowane $\mathrm{w}$ odniesieniu do nich różne terminy świadczą o akcentowanej w literaturze wieloznaczności średniowiecznej nomenklatury. Przykładem może być zamek z Głębocka koło Grodkowa, identyfikowany ze wzmiankowaną od końca XIII w. kasztelanią. Założenie to wzmiankowane było kolejno jako huse [1294], castrum [1331, 1344, 1402] i feste [1432]. Wiadomo, że obecnie znacznie zniszczony obiekt, położony w podmokłej dolinie Nysy Kłodzkiej, miał pierwotnie formę założenia typu motte, $\mathrm{z}$ okazałym głównym kopcem i przylegającym do niego podzamczem (Lehns., I, 306, II, 7; Lf, F, 4; Lf, 166, przyp. 4; SRS, VI, 108; Legut-Pintal 2017, 161-162). Zamek z Krasnej Góry koło Niemodlina poświadczono kolejno jako castrum [1307/8], curia Sonnenberg cum villa Sonnenberg [1344], a następnie wymieniono go wśród castris seu fortalicis zajętych przez Bolka II świdnicko-jaworskiego [1360] (RSB, 21; Lf, F, 10; UGBB, nr 287; Legut-Pintal 2017, 164 , ryc. 5:c; Nowakowski 2017a, 338). Mateusz Goliński zwrócił uwagę, że położenie zamku w podmokłej dolinie rzeki, z dominującym nad okolicą kopcem, mogło mieć wpływ na nadanie warowni (a później także położonej w jego sąsiedztwie wsi) nazwy zawierającej człon -berg (Goliński 2014, 799-800). Kilka razy w źródłach pojawił się zamek z Ryczenia koło Góry, identyfikowany $\mathrm{z}$ położonym nad Baryczą grodziskiem stożkowatym. Zbudowany w końcu XIII w., poświadczony był jako curia [1345], castrum [1347], hus [1353] i Haus [1365] (Lehns., I, 167-170; Inv. Glog., 29; Nowakowski 2017a, 191, 414-415). Liczne wzmianki dotyczą także zamku Meristau (obecne na gruntach wsi Osiek Grodkowski), prawdopodobnie z końca XIII w. Jako castrum biskupie wymieniony był po raz pierwszy w $1344 \mathrm{r}$. Spokrewniony z biskupem Przecławem Markward z Pogorzeli w 1367 r. przekazał bratu Stefanowi dział in firma curia Merissow. Dwa lata później, przy okazji podziału majątku rodziny Pogorzelów, obiekt nazwano Haus. Ponownie curia Meristau ujawniła się w źródłach w 1397 r., a następnie jako Burg [1415] i zdobyte przez husytów Feste [1432] (Lf, F, 1a, 2, 3, s. 165; RSW, nr 44; QGNB, nr 133, USB, nr 580; GHus., 108; Legut-Pintal 2017, 162-163).

Jak zauważył Mateusz Goliński, w niektórych wypadkach można podejrzewać, że użycie w dokumentach określenia castrum mogło być świadomym nadużyciem kancelarii książęcych i biskupich, w celu legalizacji akcji pacyfikacyjnych przeciw takim obiektom (Goliński 2005). Wiadomo, że w świetle obowiązującego na Śląsku Zwierciadła Saskiego prawo do budowy zamków mieli wyłącznie władcy terytorialni, natomiast bez ich zgody mogły być budowane tylko niewielkie obiekty mieszkalno-obronne o wyraźnie sprecyzowanej formie (Der Sachsenspiegel..., 88-89). Z prawnego punktu widzenia podjęcie działań militarnych wobec zamków uzasadnione było zatem tylko w przypadku obiektów naruszających regale grodowe. Niezwykle interesujący w tym kontekście jest omówiony ostatnio przez Tomasza Jurka przykład wymienionych w Kronice polsko-ślaskiej budowniczych zamków, przez których Bolesław II Rogatka miał utracić władzę w księstwie legnickim. Postawione w krótkim czasie (1249-1254) przez rycerzy niemieckich castra, były zapewne relatywnie tanimi i łatwymi do budowy założeniami typu motte. Niestety, źródło nie wymienia z nazwy tych obiektów i ich fundatorów, wiadomo tylko, że po odzyskaniu władzy przez księcia Bolesława zamki te zburzono (Kronika..., 652; Jurek 2012, 783-784).

Równie ciekawe są przekazy związane z założeniami w Starym Lesie koło Grodkowa i Białej Nyskiej, szczegółowo przeanalizowane przez Mateusza Golińskiego. Pierwszy z nich został zbudowany w czasie 
sporu między księciem wrocławskim Henrykiem IV i biskupem Tomaszem II. W dokumentach z $1284 \mathrm{r}$. biskup skarżył się, że książę zbudował na ziemi Kościoła fortalicium sive castrum, innym razem nazwane jako munitium, oraz na to, że do budowy [fossata fodienda] wykorzystywał jego poddanych. Rok później w dokumentach biskupich jest już wyraźnie mowa o uciążliwym dla niego castrum, które to określenie, jak uważa Mateusz Goliński, użyte zostało świadomie dla podkreślenia wagi problemu. Wzmiankowany obiekt identyfikuje się z reliktami okazałego założenia typu motte zbudowanego na północ od obecnej wsi Stary Las (SUb, V, nr 122, 124, 135, 176, 187; Goliński 2005, 41-42, 46-47; Boguszewicz 2010, 103-105, ryc. 69; Nowakowski 2017a, 187-188, 435). Z kolei zamek w Białej pod Nysą, tak jak wzmiankowany razem z nim Kaltenštejn, wzniósł książę Bolko I świdnickojaworski podczas rewindykacji dóbr w ziemi nyskootmuchowskiej. Oba obiekty jako castra i castella wymieniono w dwóch dokumentach z $1295 \mathrm{r}$. W tym samym roku biskup wrocławski domagał się likwidacji, względnie przekazania mu zamków [de castris novis demoliendis aut eisdem nobis reddendis]. Rok później ordynariusz krakowski, jako rozjemca sporu, nakazał księciu zburzenie zamku w Białej [castrum] koło Nysy i przekazanie Tomaszowi II warowni Kaltenštejn. Również w tym wypadku obiekty zbudowane naprędce, podczas działań militarnych, nie mogły być okazałymi założeniami (SUb, VI, nr 201, 204, 254; Goliński 2005, 47-48; Nowakowski 2017a, 192193, 260).

Przykład „nadużycia” terminu castrum w odniesieniu do prywatnej siedziby, odnajdujemy w rachunkach rady miejskiej Wrocławia z lat 1316-1317. Wspomniano tam o karach nałożonych na rzemieślników, którzy nie wyruszyli na wyprawę przeciwko zamkowi budowanemu [castrum edificandum] przez Merbota von Haugwitz. Skądinąd wiemy, że posiadał on dobra na pograniczu księstw legnickiego i wrocławskiego, w tym w Żerkówku koło Wołowa. Z tej miejscowości znane jest grodzisko stożkowate datowane na XIII/ XIV-XV w. Przyczyną planowanej akcji przeciw Merbotowi mogła być jego służba u księcia legnickiego, a jednocześnie budowa założenia obronnego na terenie księstwa wrocławskiego. Rzekome złamanie regale grodowego przez budowę castrum mogło być tylko pretekstem do podjęcia działań militarnych przeciw stronnikowi wrogiego księcia (RSB, 40; Goliński 2014, 817-819; Nowakowski 2017a, 200-201, 482 , ryc. 116). Bardzo późny przykład użycia terminu castrum w odniesieniu do niewielkiej siedziby rycer- skiej odnajdujemy w Roczniku głogowskim, w części opisującej zawieruchę wojenną lat 80 . XV w. Podczas jednej z wypraw książę Jan II żagański w 1480 r. miał zdobyć castrum w Naratowie koło Góry. Obecnie na terenie wsi zachowany jest nowożytny dwór zbudowany na ziemnym kopcu otoczonym częściowo zachowaną szeroką fosą (Annales..., 44; Nowakowski 2008, 510).

W kontekście rozważań nad terminem castrum zwraca uwagę użycie w kilku dokumentach jego zdrobniałej formy castellum, która w średniowieczu oznaczało różnego rodzaju urządzenia obronne, często strażnicę, małą fortecę i mały zamek (Stownik łaciny..., II, 226). Ksiega Henrykowska we fragmentach opisujących początki klasztoru, a więc odnoszących się do lat 20. XIII w., wymienia zagadkowe castella w Jagielnie i w trudnym dziś do lokalizacji Kołaczowie koło Henrykowa (KH, 15/119-120). Jak się uważa, chłop, który siedział na gródku w Kołaczowie zapewne pilnował warowni w ramach obowiązku stróży (Kajzer 1993, 93-94). Jak dotąd nie udało się żadnego z wymienionych obiektów zidentyfikować w terenie, jednak były to z pewnością założenia, które odbiegały skalą od okazałych wczesnośredniowiecznych grodów. Być może były to małe ufortyfikowane gródki z końca XII lub początku XIII w., których zadaniem było zabezpieczanie rozwijającego się $\mathrm{w}$ okolicy osadnictwa (Adamska 2019, 79, 408). Z datowanym na koniec XIII w. zamkiem w Tarnowie Jeziernym łączy się wymienionego w 1295 r. kasztelana Przybka. Rok później świadkował on na dokumencie książęcym jako Przybko z zameczku Tarnów [de castello de Tharnowo] (SUb, VI, nr 197, 244). W cytowanych już rachunkach rady miasta Wrocławia za lata 1302-1303 znajduje się notka o przekazaniu biskupowi wrocławskiemu 100 grzywien w związku z jego wydatkami przy likwidacji bliżej nieokreślonych małych zamków [castella]. W literaturze nie ma pewności o jakie konkretnie założenia chodziło, przy czym za jeden z możliwych wariantów przyjmuje się, że zbrojna akcja skierowana była przeciw zbuntowanym rycerzom (RSB, 11; Goliński 2014, 813-815). Wspomniany już obiekt z Lubrzy koło Świebodzina kilka razy wymieniono w źródłach, w tym jako castellum w 1322 r. Jeszcze niedawno w sąsiedztwie wsi (w średniowieczu miasteczka, skalą założenia nieodbiegającego od dużej wsi owalnicowej), nad brzegiem jeziora, zachowane było grodzisko stożkowate z reliktami kamiennej wieży mieszkalnej (KDW, II, nr 1030; Nowakowski 2017a, 352-353). 


\section{Hus/Haus}

Od XIV w. w śląskich kancelariach dominować zaczął język niemiecki, co oczywiście znalazło odzwierciedlenie w stosowanej nomenklaturze. W źródłach z tego okresu i późniejszych często spotykanym określeniem jest Hus/Haus, przy czym używano go, podobnie jak wcześniejszego castrum/Burg, z reguły w odniesieniu do obiektów dużych, murowanych ${ }^{10}$. Podstawowe znaczenie terminu Haus w średniowieczu było takie jak współcześnie i oznaczało dom mieszkalny w mieście i na wsi, a także na zamku, przy czym w ostatnim wypadku często używano go w odniesieniu do głównej budowli (Deutsches Wörterbuch..., X, 641-644). Również na Śląsku obiekty występujące w źródłach jako Hus/Haus to przeważnie założenia duże. Niektóre z nich zawierają w nazwach własnych człon -haus, jak np. Lähnhaus (Wleń), Neuhaus (Chałupki), Neuhaus (Wałbrzych-Nowy Dwór), Schweinhaus (Świny) i inne (Grundmann 1982; Boguszewicz 2010a, według katalogów). Zdecydowanie rzadziej jako Hus/Haus nazywano omawiane tu niewielkie siedziby pańskie.

W dokumencie z 1319 r., potwierdzającym przejęcie północnych obszarów księstwa głogowskiego przez Waldemara brandenburskiego, jako Hus wymieniono niewielkie założenia z Lubrzy i Witynia, ale także zamek miejski z Sulechowa (Lehns., I, 125-126). Wspomniany obiekt z Ryczenia jako Hus/Haus poświadczony był w 1353 i 1365 (Lehns., I, 169-170; Inv. Glog., 29). Również dwukrotnie [1361, 1419] pod tym terminem krył się zamek z Jędrzychowa, w tym czasie niewielkie założenie $\mathrm{z}$ murem obwodowym i wieżą mieszkalną (ryc. 2:f). Użyte w dokumencie z 1419 r. zwroty Haus und Schloss oraz Altars auf dem Hause wskazują, że w tym wypadku terminu Haus użyto dla określenia głównego budynku zamkowego (Lehns., I, 181, 201). W 1368 r. rycerz Konrad von Löben sprzedał księciu Konradowi II oleśnickiemu Hus w Sądowlu koło Góry. Badania archeologiczne i geomagnetyczne tamtejszego wczesnośredniowiecznego grodziska wykazały, że w jego centralnej części około połowy XIV w. zbudowano okazały dwór z kopcem o czworobocznym zarysie, fosą i zewnętrznym wałem (APWr., Rep. 33, sygn. 1242, s. 134; Kiarszys 2015, 220-225).

10 W kancelariach państwa krzyżackiego w Prusach termin Hus, tak jak łacińskie domus i castrum, zarezerwowany był dla obiektów murowanych - siedzib komtura i zamków konwentualnych (Jóźwiak, Trupinda 2012, 9697; Poliński 2018, 49-49).
Konrad Predel z Szymanowa sprzedał w 1391 r. Pessoldowi von Mesenau połowę folwarku $z$ budynkiem - zapewne gospodarczym - i domem [mit dem geboude und mit dem hause] w Olszanach w okręgu strzegomskim. Pozostałości założenia mieszkalnego są identyfikowane $\mathrm{z}$ bliżej nierozpoznanym owalnym kopcem otoczonym fosą, na plateau którego czytelny jest zarys murowanej wieży (LKŚJ, II, nr 891; Błoniewski 2017, 181-184). Relikty budowli murowanej były również widoczne na niewielkim kopcu z Kalinówki. Obiekt ten, tak jak i cała wieś, zostały zniszczone przy budowie zbiornika poflotacyjnego. W 1478 r. tamtejszy Haus i inne dobra należał do rodziny Tauerów. Już w 1518 r. zrujnowany obiekt nazwano alte Schloss, w którym dostępne były jedynie piwnice i widoczne były ślady fosy [Walgraben] (SWŚ, I, 104, Nowakowski 2017a, 321).

Prawdopodobnie na miejscu starej warowni książęcej, wiązanej ze wzmiankowanym w 1298 r. castrum Sedlscho, w końcu XV lub na początku XVI w. zbudowano dwór w Siedlisku koło Bytomia Odrzańskiego. Wzniesiony przez Rechenbergów obiekt miał formę regularnego czworobocznego założenia z murem obwodowym i długim domem we wschodniej części dziedzińca (ryc. 2:g). W 1507 r. posiadaczem des Hauses Karlat był Balthasar von Rechenberg (Inv. Grünb., 102; Kąsinowska 2003, 177-179, 185; Nowakowski 2008, 180, 536-538). Również do rodziny Rechenbergów należał wspomniany już dwór z Borowa Polskiego. W połowie XVI w. został on przebudowany, w rezultacie czego zyskał formę przysadzistego domu z narożną wieżą ze strzelnicami (ryc. 2:b). Napis z umieszczonej w jego murach tablicy erekcyjnej głosił: Ich Georg von Rechenbergk avf Wartenbergk und Windischemboraw dis Haus ym (15)48 Jar aus dem Grund erbavet und ym (15)50 Jar vorbracht (Andrzejewski 2007, 247-248).

\section{Fortalicium/Feste}

Termin fortalicium bardzo często spotykany w źródłach z terenu Królestwa Polskiego (tu odpowiednikiem było określenie twierdza), w śląskich kancelariach był raczej rzadko używany. W średniowieczu pod tym pojęciem kryły się różnego rodzaju obiekty obronne, jednak podobnie jak sporadycznie spotykanego municium, używano go najczęściej w odniesieniu do niewielkich założeń obronno-rezydencjonalnych (Stownik taciny..., IV, 329; VI, 552553; Kajzer 2010, 43-44; Nowak, Szymczak 1993, 
81-82). Jako municio seu fortalicium satis fortem w 1339 r. był opisany obiekt w Sidzinie koło Grodkowa, który wrocławski biskup wykupił z rąk Teodoryka Logau i - ze względu na gwałty, jakich rycerz się dopuszczał - nakazał go zburzyć (QGNB, nr 8; Nowakowski 2017a, 422-423). Tak jak kilka przywołanych dworów biskupich (Skoroszów, Wierzbno), jako curia fortalicio w $1340 \mathrm{r}$. wymienione też zostało założenie z podwrocławskich Bieńkowic (RF, I, 8b). Obiekt ten nie zachował się, jednak najpewniej identyfikować z nim należy, znaną z nowożytnej kartografii, murowaną siedzibę położoną w sąsiedztwie folwarku (ryc. 1:c). W 1393 r. wzmiankowano fortalicium w Pławniowicach koło Gliwic - cel ekspedycji wojsk polskich pod wodzą Piotra Szafrańca. Informację o nim zapisano w rachunkach dworu Władysława Jagiełly. Reliktem tego obiektu jest okazały czworoboczny kopiec z ruiną nowożytnego budynku na majdanie, zbudowany na owalnym plateau otoczonym fosą (Rachunki..., 168; Nowakowski 2017a, 422-423). Wiemy również, że w 1443 r. książę ziębicki Wilhelm zdobył należące do krnąbrnych panów z Warkocza warownie w Warkoczu i Jagielnie koło Strzelina oraz należący wówczas do Gotsche Schaffa obiekt w Ciepłowodach koło Ząbkowic Śląskich [obtinuit fortalitium Warkatz, fortalicium Jegil et Teppilwude]. Ostatecznie po warowni w Warkoczu miało pozostać tylko das feste Ding, a jej reliktem jest datowane na XIV-XV w. grodzisko stożkowate. W Ciepłowodach w połowie XV w. znajdowała się zachowana do dziś murowana wieża mieszkalna (ryc. 2:e) otoczona murem obwodowym i fosą (Chorowska 2003, 131-132; Nowakowski 2017a, 285, 453; Adamska 2019, 230).

Interesujących danych odnośnie terminologii dostarcza spisana w dwóch językach kronika wrocławska Piotra Eschenloera. W czasie prowadzonych w 1459 r. walk o miasto istotną rolę odegrały położone wokół niego dwory, w wersji łacińskiej tekstu określone jako fortalicia, natomiast $\mathrm{w}$ niemieckiej jako höfe. Co ciekawe, nazwane tak zostały wymienione w jednym szeregu zarówno relatywnie małe obiekty ze Złotnik (ryc. 1:b), Gałowa, Borowa i Leśnicy, jak i zamki miejskie ze Strzelina, Środy Śląskiej i Ziębic. O wartości militarnej tych pierwszych świadczyć może odnotowany w kronice opis ciężkich walk podczas oblegania dworu/fortalicji w Borowie (Eschenloer I, 61; II, 291-292; Boguszewicz 2010b, 26-29; Goliński 2017, 44). Analogicznie został określony obiekt w Jemielnej koło Bierutowa. Należące do Mikołaja Dera hofe/fortalicium zniszczyli w 1466 r. najemnicy wrocławscy, a jego pozostałością jest zapewne, położone w środkowej części wsi, grodzisko stożkowate, datowane na XIV-XV w. (Eschenloer I, 115-116; II, 529; Nowakowski 2017a, 316).

Niemieckim odpowiednikiem fortalicium było spotykane $\mathrm{w}$ późnośredniowiecznych źródłach śląskich określenie Feste/Veste. W krajach niemieckojęzycznych pod tym pojęciem kryć się miały przede wszystkim relatywnie małe założenia obronne, w łacińskich źródłach określane także jako firmamentum i munitium. Na przykładzie materiałów z Górnej Frankonii Helmut Kunstmann wykazał, że w XIV w. była to powszechnie używana nomenklatura dla tamtejszych zamków, przy czym wśród nich były także obiekty duże, a termin ten występował często w zestawieniu z Haus (Deutsches Wöerterbuch..., III, 1563-1564; Kunstmann 1967, 8). Wobec powyższych uwag interesującą wymowę ma dokument księcia opolskiego Władysława II z 1399 r. Jego bratankowie - Jan biskup w Chełmnie i książęta Bolko i Bernard - w zamian za wyrządzone krzywdy mieli przekazać wójtowi opolskiemu das Neue Haus zu Opul i die Veste Damaratcz. Nowy zamek w Opolu, położony na wschodnim obrzeżu miasta, najpewniej zbudował książę Władysław II w latach 1382-1387. Słabo rozpoznane założenia miało prawdopodobnie typowy dla zamków miejskich regularny plan, a jego elementem była czworoboczna wieża (Guerquin 1984, 242; Kołodziejski, Kajzer, Salm 2001, 354). Obiekt z Domaradza nie zachował się, jednak z danych archiwalnych wiadomo, że jego relikty w postaci ziemnego kopca otoczonego fosą i wałem, o całkowitej średnicy ok. $55 \mathrm{~m}$, położone były niedaleko wsi, w obrębie podmokłej dolinie (Nowakowski 2017a, 292). Zastosowane w dokumencie rozróżnienie na Haus i Veste wynikało zapewne z różnej formy tych obiektów, oba pełniły też inne funkcje. Pierwszy był ewidentnie rezydencją księcia i jego urzędników, natomiast drugi, położony centralnie między Opolem, Brzegiem, Namysłowem a Kluczborkiem, mógł pełnić funkcje gospodarczomilitarne (kontrola szlaków handlowych) ${ }^{11}$.

11 Inne znane ze źródeł przykłady wskazują jednak, że spotykane niekiedy w dokumentach rozróżnienie na Hus/Haus i Veste/Feste nie może być jedynym kryterium świadczącym o ich wielkości. Dobrym przykładem może być zamek Freudenberg, identyfikowany z obiektami w Mieroszowie (Friedland) lub Rybnicy Leśnej (Görbersdorf) koło Wałbrzycha. W 1374 r. wymieniony był jako das Hus Frewdenberg mit dem markte Fredelandbey derselben vesten gelegen, a kilkanaście lat później wzmiankowany już tylko jako Feste (LKŚJ, I, 909; II, nr 520; Boguszewicz 2010a, 236-237, 252-253). 
Już w 1343 r. Jan von Borsnitz kupił folwark i dwór w Marcinkowicach koło Oławy. Najpewniej jego syn w 1397 r. sprzedał wrocławskim krzyżowcom $\mathrm{z}$ czerwoną gwiazdą dobra Marcinkowice mit dem festen Hofe. Dziesięć lat później książę odkupił od nich prawo kwaterunku we wsi, wraz z zabudowaniami i festen Hofe (Rś, I, nr 29; UHLB, nr 1185; Eistert 1936, 45). Reliktem obiektu jest bliżej nierozpoznane wyniesienie położone przy północnym krańcu wsi, na krawędzi doliny Oławy (ryc. 1:d).

Mikołaj Lemberg w 1408 r. sprzedał Piotrowi von Landeskron wieś Dobrzyń koło Brzegu, wraz z festen Hoff Ottotzkÿ. Obiekt ten identyfikuje się z obecnym przysiółkiem Zamcze, położonym na wschód od wsi Błota. Być może miał on jakiś związek z komorą celną w Dobrzyniu, potwierdzoną w 1413 r. (APWr., Akta m. Wrocławia, sygn. B 89: 2, s. 59; USB, nr 724). W 1476 r. Hans Borsnitz uzyskał potwierdzenie swoich praw do majątku w okolicach Niemczy, w tym do połowy Veste w Prusach. Dwa lata wcześnie obiekt ten [Hoff] nabył Zygmunt von Rotinburg (APWr., Akta m. Wrocławia, sygn. B 89: 4, s. 81-81v, 87). Wiemy również, że w Białej koło Nysy mieszczanin Hans Nimptsch miał w 1487 r. dwie puste parcele, na których zbudowal eyne neue Feste. Prawdopodobnie tego samego obiektu dotyczył zapis z 1613 r., mówiący o zarybieniu Wahlgraben und Inselgraben in Bylaw (Lorenz 1939, 15).

Interesujące przekazy źródłowe dotyczą obiektu z Łabędów (obecnie część Gliwic). W 1472 r. biskup wrocławski rozstrzygnął spór między książętami Mikołajem opolskim i Przemkiem toszeckim tak, że Veste Labuthi miała należeć do księcia opolskiego. Kilka miesięcy wcześniej przedstawiciele ziemi sosnowieckiej i strzeleckiej oświadczyli, że wieś i twierdza [tvrz] położona w okręgu sosnowieckim należy do książąt opolskich. Przywołane dane łączyć należy z jednym $\mathrm{z}$ dwóch znanych $\mathrm{z}$ Łabędów grodzisk stożkowatych, niestety, oba zostały niemal całkowicie zniszczone (RSW, nr 287, 290, 291; Nowakowski 2017a, 353-354). Również jako tvrz w 1535 r. określony został obiekt $\mathrm{z}$ Tworkowa koło Raciborza (LOR, nr 15). Być może identyfikować go należy $z$ rozległym czworobocznym plateau otoczonym rowem, zachowanym w parku na północ od wsi. Użyty termin tvrz w dokumentach spisanych w języku czeskim jest przejawem silnych związków kulturowych Górnego Śląska z obszarami Czech i Moraw. W tamtejszych kancelariach używano pojęcia w odniesieniu do mniejszych założeń obronno-rezydencjonalnych. Wśród nich były zarówno obiekty typu motte, jak i niewielkie murowane dwory, niekiedy o złożonych programach zabudowy (Nekuda, Unger 1981; Svoboda i in. 1998; Plaček 2001).

\section{Propugnaculum, Bergfried, Wall, kopiec}

Obronny charakter siedzib pańskich potwierdzają także spotykane w źródłach terminy odnoszące się do ich elementów warownych, kryjących się za określeniami typu propugnaculum, bergfried, Wall, Graben i sporadycznie także innych. Szczególnie liczne przykłady odnajdujemy w dokumentach dotyczących obiektów z okolic Wrocławia. Większość z nich była położona w niewielkich wsiach folwarcznych i przeważnie należała do tamtejszych patrycjuszy. Niestety, tylko nieliczne zachowały się do czasów współczesnych.

Drugiej połowy XIII w. sięgają początki folwarku Magnice. W 1336 r. Jan Reste kupił od Boguszki Sebinwirta połowę tamtejszego allodium z dworem i ufortyfikowaną siedzibą [curia cum propugnaculo, quod wlgo Berffrit nominatur]. Obiekt ten powiązać należy z położonymi w zachodniej części wsi ruinami bliżej nierozpoznanego murowanego dworu zbudowanego na okazałym ziemnym kopcu, z trzech stron otoczonym szeroką fosą i wałem zewnętrznym (RS, nr 5746; Nowakowski 2017a, 355-356, ryc. 58:4). Do Jana Reste należały także dobra w sąsiednim Wilczkowie, gdzie w 1355 r. miał on allodium cum propugnaculo et curia fossatis circumdata et alia ipsius allodii curia, zapisane wówczas synowi Janowi (RF, IV, 2926). Zapewne z tym obiektem identyfikować należy murowany dwór $\mathrm{z}$ fosą, wyrysowany na nowożytnej kartografii w sąsiedztwie folwarku, w północno-wschodniej części wsi ${ }^{12}$.

W 1321 r. Henryk VI wrocławski przekazał za wierne służby rycerzowi Tyczkowi de Stercza dobra Krobielowice koło Kątów Wrocławskich. Osiem lat później posiadający dział w sąsiednich Wojtkowicach Pogorzelowie zrzekli się na rzecz Tyczka swoich pretensji do praw zwierzchnich nad dworem i allodium. Kolejny właściciel majątku, Henryk Wüstehube, w 1346 r. sprzedał mieszczaninowi wrocławskiemu Petrowi Schwarz, na prawie lennym, allodium z połową ufortyfikowanego dworu i należącym do niego

12 Mapa L.W. Reglera z lat 1764-1770, arkusz nr 60 (Staatsbibliothek Berlin, Preußischer Kulturbesitz, sygn. 15140); Urmestischblatt z 1824 r., arkusz nr 2954 (Staatsbibliothek Berlin, Preußischer Kulturbesitz, sygn. N 729). 
młynem [mediam partem munitionis seu curia sua et molendini curiae adjucentis]. Ponownie tamtejszy dwór jako allodium seu curia wymieniono w $1352 \mathrm{r}$. (RS, nr 4103; 4826; RF, I, 301, 511). Reliktów tego obiektu szukać należy w obrębie nowożytnego pałacu w dolinie Czarnej Wody (ryc. 3:a). Przykładem dobrze zachowanego założenia jest grodzisko stożkowate z położonej na północ od Wrocławia Mokrej. Z nim identyfikować należy wzmiankowaną w 1346 r. dwór $\mathrm{z}$ wieżą [curia prope Ecclesiam in qua stat propugnaculum] (RF, II, 775). Podczas badań archeologicznych na plateau kopca odkryto pozostałości ceglanej wieży datowane na XIV-XV w. (Nowakowski 2017a, 368369 , ryc. 59).

Liczne przekazy dotyczą obiektu ze Strachowic, który w źródłach pojawia się jako propugnaculum et curia [1330], propugnaculum Bergkfridt vulgo nuncupatur [1349], propugnaculum Bergfriede [1362], fuhrwergk zu Strachwitz beÿ dem Burgfriede und auswendig das Hoff oder Hoffraite [1370] (RF, IV, 2740, 2748, 2752, 2756). Również to założenie znane jest tylko z dawnych planów wsi, na których zaznaczono murowany budynek na wysepce otoczonej fosą (ryc. 3:b). W Jutrocicach Dolnych koło Nysy w 1364 r. córki mieszczanina Konrada Slusera sprzedały dział ziemi we wsi cum area propugnaculi et ipso propugnaculo (QGNB, nr 54; APWr., Rep. 31, sygn. 1A, 9). Z kolei rok później rycerz Beczon z Gułowa koło Strzelina zapisał żonie curiam habitationis cum propugnaculo (Eistert 1936, 44).

Wyłącznie ze źródeł pisanych znany jest obiekt ze Świętej Katarzyny koło Wrocławia. W 1339 r. Mikołaj Kuntschatke, najpewniej mieszczanin wrocławski ${ }^{13}$, kupił od chłopa Maćka łan pola we wsi wraz z należącą do niego zagrodą [cum curia]. Jego potomek, Marcin Kuntschatke, sprzedał w 1364 r. Mikołajowi Losar 2 lany we wsi cum area mansione domo et propugnaculo (RF, III, 280, 284; SR, nr 6268). Według niemieckiego regestu dokumentu z 1373 r. do rycerza Peszka z Borucina koło Raciborza należało założenie obronne określone jako Burg. Siedzący tam rycerz Jerzy w 1382 r. posiadał das Berkfrede das genant ist dy Westhe (RSW, nr 51; NAP, RML, nr 2006). Obec-

13 Być może domniemana rodzina mieszczan wrocławskich Kuntschatke (Pfeifer 1929, 168) miała jakiś związek z rodziną rycerską z Kurzątkowic koło Wiązowa, a ich nazwisko mogło powstać w wyniku fonetycznego przekształcenia. O rycerzach z Kurzątkowic słyszymy jeszcze w latach 50-60. XIV w. (UHLB, nr 107, 288, 466; Adamska 2019, 221). nie założenie to jest znacznie zniwelowane, jednak $\mathrm{z}$ danych archiwalnych wiadomo, że było to okazałe grodzisko stożkowate otoczone szeroką fosą i wałem zewnętrznym (Nowakowski 2017a, 270-271).

Od 1317 r. są poświadczone dobra rodziny rycerskiej Rimbabe w Piotrowicach koło Środy Śląskiej. W 1402 r. Henryk Rimbabe sprzedał Piotrowi Dieschkowitz trzecią część am Fuhrwergk das Gesäß und Gebeudt. Cztery lata później tenże Piotr odkupił od Jana Rimbabe pozostałe dwie trzecie, z tym że wówczas już zapisane jako am Fuhrwergk Gesäß, Bergfriede (RF, II, 969, 972). Wyjątkowo jako Bergfart w 1413 r. nazwano siedzibę sołtysa w Kościerzycach koło Brzegu, który uzyskał wówczas zgodę na jej ufortyfikowanie [ummeblanken]. Jedynie $\mathrm{z}$ danych archiwalnych wiadomo, że gdzieś na terenie wsi znajdowały się relikty grodziska stożkowatego (USB, nr 720; Eistert 1936, 45; Nowakowski 2017a, 335).

Wymienione wyżej określenia propugnaculum i Bergfried w średniowieczu miały szersze znaczenie. Używano ich także w odniesieniu do innych elementów fortyfikacyjnych (np. obronnych wykuszy, wież zamkowych, wież w murach miejskich), a niekiedy nawet do obiektów niezwiązanych z budownictwem obronnym, takich jak urządzenia handlowe (Stownik taciny..., VII, 1308; Binding 1980, 1955-1956). W literaturze zwrócono również uwagę, że terminami tymi określano niekiedy także główne człony (kopce) obiektów typu motte (Bouard 1967, 21-23; Hinz 1981, 53-58). W takim znaczeniu propugnaculum użyto w dokumencie z 1357 r. dotyczącym Smolca Małego koło Kątów Wrocławskich (obecnie północna część Smolca). Hanko Jesir sprzedał wówczas Mikołajowi Melereschowi 5 łanów we wsi cum medietate area propugnaculi quod vulgariter ein Wahl dicitur. W późniejszych przekazach obiekt ten wymieniono jeszcze jako das Waal und Gesäß darbeÿ [1421] i fuhrwergk, Waal, Gesäß [1452] (RF, III, 2352-2353).

W kilku dokumentach odnajdujemy określenie Wall oznaczające ziemny nasyp pod budynek mieszkalny lub innego rodzaju zabudowę. Interesujący przekaz dotyczy okazałego założenia typu motte z Tarnowa Jeziernego koło Głogowa. Obiekt ten w drugiej połowie XIV w., jako lenno i zastaw, należał do rodziny von Rechenberg. W 1399 r. książę legnicki Ruprecht udzielił zgody na budowę wału [wall] w Tarnowie. Badania archeologiczne wykazały, że ów wał można powiązać z najmłodszą fazą użytkową drugiego członu warowni, przebudowanego na przełomie XIV i XV w. W rezultacie nasyp zyskał formę regularną, z czworobocznym plateau (Inv. Grünb., 106; No- 

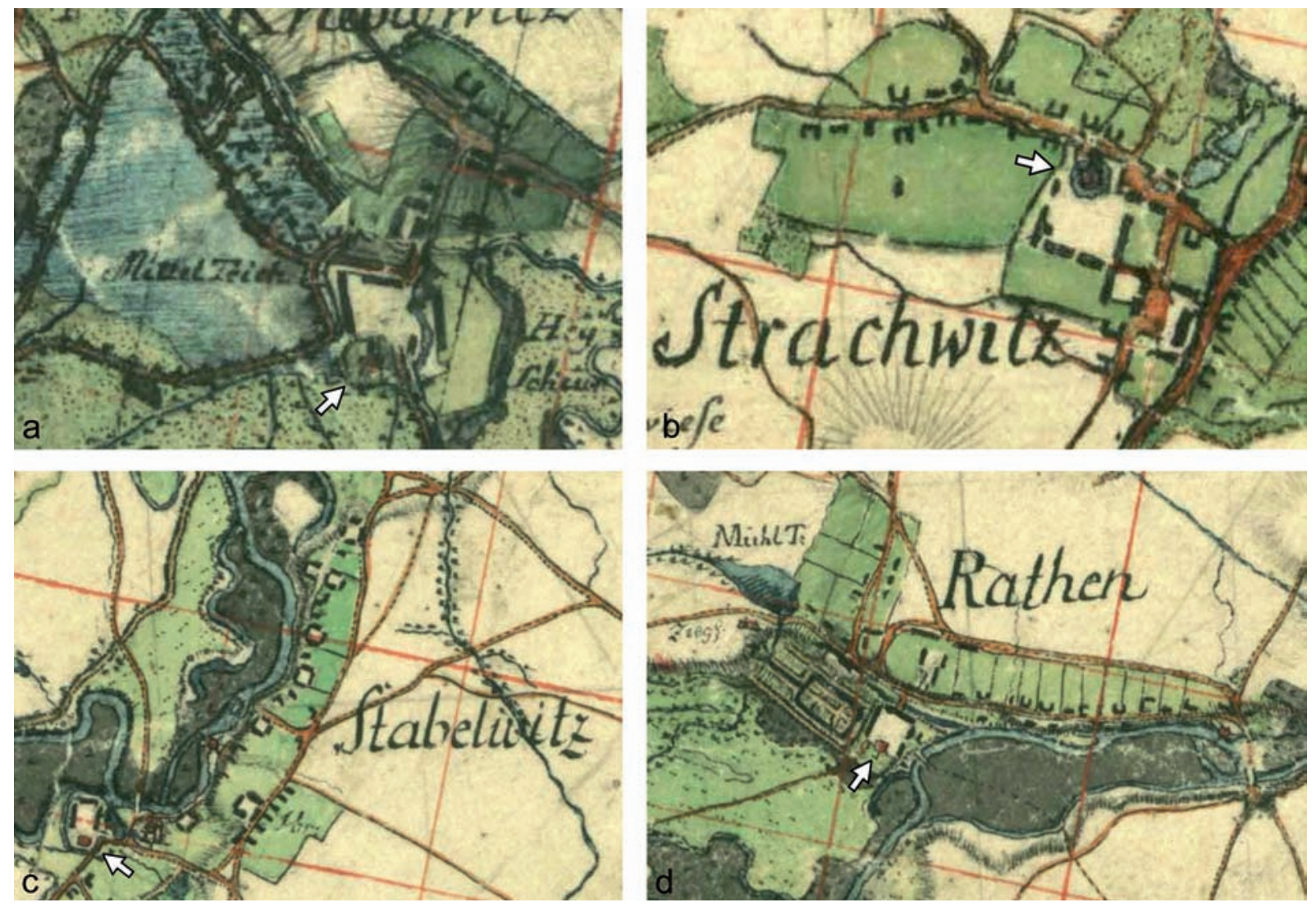

Ryc. 3. Plany wsi z lokalizacją obiektów obronno-rezydencjonalnych wg XVIII-wiecznych map L.W. Reglera: a) Krobielowice; b) Strachowice; c) Stabłowice; d) Ratyń (Staatsbibliothek Berlin, Preußischer Kulturbesitz, sygn. N 15140)

Fig. 3. Plans of the village with the location of defense and residential objects according to the 18th-century maps of L.W. Regler: a) Krobielowice; b) Strachowice; c) Stabłowice; d) Ratyń (Staatsbibliothek Berlin,

Preußischer Kulturbesitz, sign. N 15140)

wakowski 2017a, 444-446, ryc. 58:3, 354). Dwa lata później sołtys położonych na południe od Wrocławia Wilkowic oświadczył, że należy do niego Wall mit Graben, 8 i 1/4 dziedzicznych łanów oraz 2/3 młyna w niedalekich Pasterzycach. W 1410 r. dokupił kolejne 4 łany i pozostałą trzecią część na młynie i wale [an der Mühle und Walle] (RF, II, 921, 924). Wieś Pasterzyce powstała z przekształcenia poświadczonego w połowie XIV w. folwarku. Na nowożytnych planach widać młyn na Ślęży i siedzibę pańską, po której do dziś zachował się nasyp częściowo ogrodzony szeroką fosą.

Z górnośląskich Woźnik znane jest znacznie zniwelowane grodzisko stożkowate, $\mathrm{z}$ czworobocznym kopcem otoczonym fosą i wałem zewnętrznym. W 1386 r. Władysław opolski przekazał Markowi zw. Jochs castrum seu fortalicium, natomiast w 1412 i 1418 r. przedmiotem transakcji było położone pod miasteczkiem Walle oder Veste (RSW, nr 128, 150; Nowakowski 2017a, 465-466). Należąca do wrocław- skiej kapituły katedralnej wieża mieszkalna w Biestrzykowie koło Wrocławia, w 1410 r. wzmiankowana była jako turra murata, natomiast w 1447 r., obiekt ten opisano jako kopiec z wieżą i fosą wokół kopca [der Wall mit dem Turme, die Graben um den Wall] (PBD, 136; AAWr., dok. chron., sygn. 15.06.1447; Degen 1965, 45-47; Chorowska 2003, 145-147; Nowakowski 2017a, 264-265).

Interesujących danych, także w kontekście omawianej wcześniej relacji siedzib pańskich i folwarków, dostarcza dokument z 1413 r. o wsi Pomorzowice koło Głubczyc. Przedmiotem sprzedaży był położony na terenie osiedla Hof oder Vorwerk mit dem Walle dos darzu gehoret. We wsi są zachowane relikty dwóch gródków stożkowatych, oba położone w sąsiedztwie folwarków (RSW, nr 132; Nowakowski 2017a, 396-397). Jednoznaczna jest wymowa nomenklatury obiektu z Sarb Górnych koło Strzelina. Siedzący tam w 1464 r. Jerzy Wadelwitz sprzedał wieś Urbanowi Stoschowi, zawierając z nim umowę w sprawie kosz- 
tów ewentualnej budowy siedziby pańskiej. W dokumencie zaznaczono, że jeżeli Urban zbuduje coś na wale we wsi [würde off das Wall eyn dem Dorfe was bawen], to w momencie wykupu dóbr, Jerzy Wadelwitz ma zwrócić mu połowę poniesionych kosztów (APWr, WSPŚ, Kr. Strehlen, sygn. 770, teczka Willme; Nowakowski 2017a, 418).

Wątpliwości interpretacyjnych nie budzi także przekaz dotyczący siedziby w Maszkowicach koło Otmuchowa. Rycerz Piotr Schaff w 1489 r. zapisał w spadku nyskim radnym swoje dobra we wsi, pozostawiając dla siebie do użytkowania das Haus auf dem Wall i inne nieruchomości, w tym Hof (Inv. Nei., 68-69). Z kolei inwentarz majątku zaginionego folwarku Schilde (obecnie w granicach Głębinowa koło Nysy) z 1539 r. podaje, że miał się przy nim znajdować mały drewniany zameczek [Schlossel] o wysokości dwóch pięter, który położony był na wale otoczonym fosą [an einem Walle mit Wasser umbschlossen ist]. Obiekt ten identyfikować możemy z niewielkim gródkiem stożkowatym, datowanym na XIV-XVI w. (Lorenz 1939, 17; Nowakowski 2017a, 421).

Znamy również przykłady użycia terminu Wall we współczesnym znaczeniu tego słowa. Być może końca XIII w. sięgają początki dworu w Krajkowie koło Wrocławia. Dobra we wsi nabył mistrz Wiland w 1284 r. od księcia Henryka IV. Jego potomkami byli piszący się z Krajkowa mieszczanie wrocławscy. W 1345 r. Osanna zrezygnowała na rzecz Michała z Krajkowa z działu ziemi i domku [domunculum] położonego przy dworze [curia] Mikołaja. Pięć lat później ten sam Michał przejął od braci Mikołaja i Wilanda kolejną część pola z placem i nasypem, potocznie zwanym wałem [cum area et aggere, quod vulgariter ein Wall dicitur] i ich zagrodę [ortus] położoną naprzeciwko miejsca, gdzie był plac [area] Wilanda z łąką i groblą zwaną potocznie tamą [cum prato et obstaculo quod vulgariter ein Thamm appellatur]. Ponownie dwór [curia] Mikołaja z Krajkowa został wymieniony w 1362 r. (SUb, V, nr 499; RS, nr 1856; RF, I, 487, 490). Z przytoczonych fragmentów wynika, że potomkowie Wilanda faktycznie mieszkali w Krajkowie i dysponowali kilkoma działami: Osanna miała 1/2 łanu i niewielki domek, a do Mikołaja należał bliżej nieokreślony dwór. Kwestią otwartą pozostaje natomiast funkcja wymienionych w dokumencie wałów. Położenie wsi w sąsiedztwie doliny Żurawki sugeruje, że któryś z nich mógł pełnić funkcje przeciwpowodziowe.

$\mathrm{Za}$ bezprecedensowy pod względem precyzji można uznać opis siedziby ze Szczepanowa koło
Świdnicy. W 1369 r. Wincenty von Nimptsch kupił dem obirsten hof mit allen seinem walen, die darzu gehoren, und die auch der euzzerste grabe deßelben hofes umbfangen hat, mit dem nadirsten hofe, da die scheunen stehen, und da die hofeleute pflegen $z u$ wonen. $\mathrm{Z}$ tekstu jednoznacznie wynika, że było to dwuczłonowe założenie $\mathrm{z}$ siedzibą [obirsten hof] ufortyfikowaną fosą i zewnętrznym wałem, $\mathrm{z}$ dworem gospodarczym [nadirsten hofe], gdzie stały stodoły i mieszkała czeladź [hofeleute]. Badania architektoniczne nowożytnego dworu na kopcu w Szczepanowie wykazały, że najstarszym elementem założenia jest niewielka murowana piwnica wieży mieszkalnej, której wyższe kondygnacje prawdopodobnie zbudowano w konstrukcji fachwerkowej (LKŚJ, I, nr 340; Błoniewski 2017, 246-258).

Synonimami dla terminu Wall, rozumianego jako nasyp pod budynek mieszkalny, były znane z nielicznych dokumentów niemiecki Berg, łaciński mons oraz polski kopiec. W Miękini koło Środy Śląskiej od połowy XIV w. do lat osiemdziesiątych kolejnego stulecia dobra mieli rycerze $\mathrm{z}$ niedalekich Jarząbkowic. Zapewne ich dziełem był obiekt odnotowany w 1509 r. jako Gesäß. Dwa lata później sprzedano tamtejszy folwark i siedzibę na wzgórzu [Gesäß am Berg] (RF, II, 818-823). W położonej na płaskim terenie wsi nie ma żadnych wyraźnych wzniesień, wobec czego wydaje się, że użyte w dokumencie określenie am Berg oznaczało po prostu nasyp, na którym zbudowano siedzibę. Prawdopodobnie jej reliktem jest owalne wyniesienie otoczone rowem, przylegające od północy do barokowego pałacu.

Niekiedy wyżej wymienionych określeń używano przy opisie reliktów obiektów, których głównym elementem był ziemny nasyp. W takim znaczeniu termin mons użyto $\mathrm{w}$ dokumencie o zamku z Jędrzychowa koło Polkowic. W 1331 r. książę Jan ścinawski nadał Janowi von Dohna wieś i stare wzgórze zamkowe zwane potocznie grodem [antiquum montem castri qui vulgariter ein burgwoll nuncupatur]. Zamek w Jędrzychowie to obiekt o typowo nizinnej lokalizacji, wobec czego można przyjąć, że zawarta w tekście charakterystyka dotyczyła zrujnowanego obiektu typu motte. $\mathrm{Z}$ planów archiwalnych wynika, że było to prawdopodobnie duże, dwuczłonowe założenie, na którego głównym członie w XIV w. zbudowano zamek murowany (RS, nr 5016; Chorowska 2003, 204205; Nowakowski 2017a, 317-318).

Pośrednim świadectwem znajomości terminu kopiec na Śląsku już w średniowieczu może być nazwa wsi Kopice pod Grodkowem, będąca przykładem tzw. 
toponimu obronnego. W źródłach nazwa wsi była zapisywana jako Copiz [1289], Copitz [1300] i Coppicz [1319], natomiast w 1344 r. wymieniono curia in coppitz cum villa Coppitz. Zbudowany na terenie wsi obiekt warowny, obecnie znacznie przekształcony, figurował wśród warowni biskupich [castra seu fortalicia] zajętych w 1360 r. przez Bolka II świdnickojaworskiego (SUb, V, nr 415; Lf, B, 402; SR 3934; Lf, F, 7; UGBB, nr 287; Nowakowski 2017a, 333-334).

Na gruntach wsi Siedlce koło Oławy lokalizowane są relikty warowni identyfikowanej w literaturze z zagadkowym grodem/zamkiem Malgost. Jerzy Sagadil w 1362 r. sprzedał czwartą część swoich dóbr w Siedlcu, w tym fragment wykarczowanego lasu cum municipium, quod in vulgari nominatur Burkwal (APWr., Rep. 21, sygn. 1A, 116; UHLB, nr 463; Eistert 1931). W górnośląskich Kochłowicach w 1467 r. sprzedany został folwark położony u kopcza kochlowskiego wedle stawu mlynskeho. $\mathrm{Z}$ tekstu wynika, że czytelne $\mathrm{w}$ terenie relikty okazałego założenia typu motte w tym czasie służyły już tylko jako punkt orientacyjny (RSW, nr 280; Nowakowski 2017, 331-332). Podobnie, w 1549 r., gdy biskup wrocławski sprzedał dział ziemi w Wierzbnie koło Nysy, jego lokalizację określono jako bey dem alden Wale (Lorenz 1939, 17). Przykład użycia terminu kopiec odnajdujemy jeszcze w sporządzonej w 1655 r. wizytacji dóbr w Sadkówku pod Wrocławiem, gdzie siedzibę rycerską opisano jako auf einer Kopitz, mit einem Wall umgeben, ein Haus (Degen 1965, 150). W tym wypadku, podobnie jak w przywołanym casusie ze Szczepanowa, termin Wall użyto w odniesieniu do ziemnej fortyfikacji otaczającej siedzibę pańską.

\section{[Gesesse], Sitz, Rittersitz}

W świetle zebranych materiałów źródłowych z XV w. obok nadal używanego Gesesse pojawiło się określenie Sitz. Liczne przykłady obu terminów odnajdujemy w dokumentach lennych dla rycerstwa księstwa żagańskiego oraz w młodszym spisie szlachty księstwa oleśnickiego ${ }^{14}$. Dla większych założeń

14 1474: Pause (obecnie część wsi Dobre); 1474 i 1508: Gesesse i Sitz w Chotkowie; 1494 i 1508: Gorzupia Dolna; 1474 i 1508: 2 obiekty w Jeleninie; 1474: Konin Żagański; 1474 i 1508: Miodnica; 1474 i 1508: 2 obiekty w Siecieborzycach; 1474: Straszów; 1474: Wilczyce; 1474 i 1508: Witków; 1474: Witoszyn Dolny (RSL, nr 11, 12, 15 , $16,17,23,28,35,39,42,43,46,65,78,85,96,99,102$, obronno-rezydencjonalnych wówczas, jak i później, zarezerwowane było określenie Schloss, stanowiące odpowiednik wcześniejszego castrum i Burg. Incydentalnie terminu tego używano dla relatywnie małych obiektów, czego przykładami mogą być wspomniane już zamki z Jędrzychowa [1419] i Ryczenia [1495] (Lehns., I, 201; II, 110). W akcie z 1444 r., potwierdzającym rezygnację biskupa Konrada oleśnickiego z diecezji i zadłużonego księstwa nysko-otmuchowskiego, w jednym rzędzie jako slöszir wymieniono różnej wielkości zamki w Otmuchowie, Friedeberg (Žulová), Freiwaldau (Jesionik), Kaltenstein (Kaltenštein), Chałupkach koło Paczkowa, a także w Wierzbnie i Ujeźdźcu koło Nysy (Lehns., II, 263).

$\mathrm{Na}$ podstawie analizy formalnej zachowanych obiektów, określanych w źródłach z XV w. jako Gesesse i Sitz, można stwierdzić, że nazywano tak różnego typu założenia. Wśród nich spotykamy zarówno bliżej nierozpoznane grodziska stożkowate, jak i przykłady murowanych wież mieszkalnych, które niekiedy, tak jak w Witkowie koło Szprotawy, budowano na ziemnych kopcach. W Dzietrzychowicach koło Żagania kamienną wieżę postawiono na naturalnym wyniesieniu. Obiekt ten z pewnością wyróżniał się w krajobrazie wsi, skoro w 1474 r. został opisany w sposób szczególny jako nieder Sitz mit dem Turme. Wyraźne podkreślenie, że chodzi o obiekt $\mathrm{z}$ wieżą, pośrednio może świadczyć o tym, że znana z Dzietrzychowic druga siedziba pańska (także należąca do rodziny von Promnitz), położona w górnej części wsi, budowli takiej nie miała (Steller 1940, 78; Nowakowski 2008, 461-465).

Przekazy wyjątkowe - ze względu na precyzję opisu - dotyczą siedziby pańskiej nadwidawskich

259); 1479: Płakowice (obecnie część Lwówka Śląskiego (NAP, RML, nr 517); 1491: Sadowice k. Wrocławia (RF, III, 268); 1530: Budzicz k. Trzebnicy; 1529/30: Dziadów Most k. Oleśnicy; 1527/33: Jagoszyce k. Prusic; 1530/37: Kosinowo k. Prusic; 1530: Mikowice k. Namysłowa; 1530: Kowale k. Trzebnicy; 1521/30: Kuraszków k. Trzebnicy (RSW, nr 508); 1537: Ligota k. Trzebnicy; 1530: Machnice k. Trzebnicy; 1530/38: Masłów k. Trzebnicy; 1530/33: 2 siedziby w Miłocicach k. Jelcza-Laskowic; 1530: Oborniki Śląskie k. Trzebnicy; 1530: Osolin k. Trzebnicy; 1530: Pielgrzymowice k. Namysłowa; 1530: Pietrzykowice k. Trzebnicy; 1530: Posadowice k. Bierutowa; 1530: Psary k. Trzebnicy; 1530: Radzowice k. Oleśnicy; 1530: Raków k. Trzebnicy; 1530: Sątok k. Bierutowa; 1530: Skokowa k. Prusic; 1530: Sokołowice k. Oleśnicy; 1529/32: Strupina k. Prusic; 1530 : Wilczyn k. Wrocławia; 1530: +Wrzigrudt (Pfotenhauer 1887, s. 323-348, przyp. $19,45,52,72,75,78,93,106,110)$. 
Stabłowic pod Wrocławiem, w których w średniowieczu funkcjonowało kilka folwarków i młynów. Już w 1346 r. Tammo Schirowsky sprzedał mlyn z prawem połowu ryb na rzece, na odcinku do mostu prowadzącego do jego dworu [ad primum pontem curiae suae]. Prawdopodobnie ten sam młyn sprzedany został w $1370 \mathrm{r}$. wraz z prawem połowu ryb bis an die erste brücke, und an die förderste [brücke]des hofes. W 1404 r. mieszczanin wrocławski Andreas Peiser kupił od Paula Schellendorfa wieś Stabłowice na prawie lennym, z folwarkiem i dworem. Piętnaście lat później wdowa po Andreasie sprzedała Fuhrwergk, Hoffe, und Gesäß z młynem, z położonym obok niego gruntem zalewowym [werder] i stawem młyńskim biß an die erste Brücke des fördersten Hofs. Kluczowe informacje na temat obiektu ze Stabłowic, także ułatwiające odczytanie wcześniejszych przekazów, zawarto w dokumencie z 1492 r., którym potwierdzono zakup całej wsi przez mieszczanina Kaspra Poppelau. Wśród licznych posiadłości wymieniono m.in. folwark przy rzece Bystrzycy i szachulcowy dwór służby [Knechtlehem Hoff]. Ponadto król zezwolił na budowę i polepszenie dworu $\mathrm{z}$ użyciem cegieł i drewna, a także na ufortyfikowanie go rowem $\mathrm{i}$ innymi umocnieniami zewnętrznymi [zu bauen und zu bessern am Hoff mit Ziegeln oder Holtz, auch von neuen $z u$ bauen und zu befestigen mit Gräben und Fuhrwergken] (RF, IV, 2672-2677, 2688-2689). W świetle powyższych dokumentów obiekt ze Stabłowic składał się z dwóch członów, to jest $\mathrm{z}$ gospodarczego [fördersten Hof = Knechtlehem Hoff] i właściwej siedziby obronno-rezydencjonalnej [Gesäß, Hoff]. Z cytowanego fragmentu wynika również, że użyte określenie Fuhrwergken (Vorwerken) oznaczało jakieś elementy warowne. W literaturze termin Vorwerk, jako rodzaj umocnień, nie jest jednak ściśle zdefiniowany. Stosowano go dla różnych, przeważnie autonomicznych fortyfikacji, które budowano przed zasadniczym pasem murów zamku lub miasta, np. dla bastionu, przedbramia, barbakanu. W tym znaczeniu termin Vorwerk znany jest jednak przede wszystkim z nowożytnych źródeł (Kratzke 2005, 178-179). Dla Stabłowic użyto go przy opisie niewielkiej wiejskiej siedziby i to chyba będącej w nienajlepszym stanie, skoro przewidywano jej przebudowę. Obiekt ten, obecnie znacznie zniwelowany i wkomponowany w założenie parkowe, znany jest przede wszystkim z nowożytnej kartografii (ryc. 3:c). Prawdopodobnie jako Vorwerk określono wał zewnętrzny, być może wyposażony w dodatkowe elementy fortyfikacyjne (w basteję?). Ze Śląska znamy późne przykłady dworów na kopcach otoczo- nych okazałymi wałami, niekiedy wyższymi niż sam nasyp (kopiec). Dobrym przykładem może być obiekt z Bełcza Małego koło Wąsosza, którego czworoboczny nasyp okala szeroki i wysoki wał, w części północnej i zachodniej przyjmujący formę wysuniętych poza jego lico ziemnych platform (Kiarszys 2015, 132, 228229; Nowakowski 2017a, 257-258). Pod względem formalnym założenia te przypominają znane $\mathrm{z}$ terenu Polski „dwory za wałem” (Kajzer 1993, 172-174).

Również bardzo szczegółowo została opisana siedziba z Ratynia koło Wrocławia. Niestety, także ona została niemal całkowicie zniszczona i znana jest przede wszystkim z nowożytnych planów wsi, na których w sąsiedztwie folwarku zaznaczono niewielki budynek murowany o kwadratowym rzucie (ryc. 3:d). W 1524 r. mieszczanin wrocławski Stefan Joppener sprzedał Dipprandowi Reibnitzowi swój dział na siedzibie [Gesäß] w Ratyniu, a mianowicie wieżę wraz z małym budynkiem obok niej [den Thurm sambt dem kleinen gebäude darneben], mostem prowadzącym do dworu [Hoff], łaźnią, browarem i piekarnią [die Badstube, Bräu- und Backhauß], a także z małym mostem i placem przed mostami, aż do zbiorników na ryby [Helder] i do sadu, tak daleko jak sięga płot, względnie jak obejmuje tenże plac (RF, III, 2080).

Podobnie jak termin tvrz, także incydentalnie wymienione określenie sidlo można uznać za przejaw bliskich relacji księstw górnośląskich z Czechami i Morawami. Przez autora regestu dokumentu przetłumaczono je jako Wohnsitz, które w 1538 r. w Zbrosławicach koło Pyskowic otrzymała żona Jerzego Kralitzkiego (LOR, nr 158).

Od XV w. dla określenia siedzib pańskich zaczęto używać terminu Rittersitz. W zebranym materiale najstarszy przykład jego zastosowania dotyczy Wymiarek koło Żagania, gdzie w 1469 r. swoją siedzibę [Rittersitz] miał Piotr von Melhoze (RSL, nr 174). Określenia Rittersitz i Rittergesesse często spotykamy w XV-wiecznych źródłach łużyckich, w tym w granicznym okręgu zgorzeleckim ${ }^{15}$. Kolejne przykłady ze Śląska znamy dopiero z przekazów z początku XVI w. W Mirocinie Dolnym koło Kożuchowa do 1505 r. posiadaczami siedziby rycerskiej [Rittersitz], poświadczonej jako Hofe już w 1429 r., byli przedstawiciele rodziny von Ebersbach (Inv. Grünb., 144, 145). Siedzący w Chotkowie koło Żagania Nostitzowie mieli dwie siedziby we wsi, w tym wymienioną w $1508 \mathrm{r}$. Rittersitz bei der Kirchen (RSL, nr 78). Na ich miej-

15 Historisches Ortsverzeichnis von Sachsen: https:// hov.isgv.de 
scu, prawdopodobnie z wykorzystaniem elementów starszych założeń, w XVI w. zbudowano renesansowe dwory (Kąsinowska 2003, 139-144; Nowakowski 2008, 444-446, 506-508). Nieco innego określenia użyto dla opisu okazałego, dwuskrzydłowego dworu z wieżą mieszkalną z górnośląskiego Chudowa, który w 1532 r. nazwano ein edelmans gesess (APWr, Rep. 4f, sygn. 151, k. 260v; Nocuń 2019). Kilka dalszych przykładów Rittersitzes odnajdujemy także w przywoływanym już spisie szlachty księstwa oleśnickiego ${ }^{16}$. Założenia te różniły się jednak formalnie, być może także ze względu na użyte do ich budowy materiały, bowiem tylko niektóre $\mathrm{z}$ nich wymieniono jako gutten sytz/gutten ryttersytz. Źródła ikonograficzne potwierdzają, że na obszarach położonych na wschód od Odry siedziby pańskie, pod względem formalnym, nawiązujące do dworów na kopcach, użytkowano jeszcze w czasach nowożytnych. Tu też przez długi czas podstawowym surowcem budowlanym było drewno i glina. Z przekazu F.A. Zimmermanna wynika, że w końcu XVIII w. na terenie księstwa oleśnickiego było zaledwie siedem dobrych siedzib pańskich [gute herrschaftliche Schlösser], a pozostałe obiekty mieszkalne były zbudowane $\mathrm{z}$ drewna [Die Wohnungen des gemeinen Mannes sind in den Waldgegenden von Schrotholz, in den meisten Dörfernn von Bindwerk] (Zimmermann 1785, 231-232).

Termin Rittersitz powszechnie używano także w czasach nowożytnych ${ }^{17}$. Można przywołać przykład murowanego dworu z Wojnowic koło Wrocławia. W pierwszej ćwierci XVI w. miał on formę dwuskrzydłowego założenia na planie litery L, z czasem rozbudowano go do okazałego dworu $\mathrm{z}$ wewnętrznym dziedzińcem. Jego fundatorami byli Schewitzowie - rodzina patrycjuszy wrocławskich. W 1544 r. Mikołaj Schewitz, nazwany rycerzem na Wojnowicach, sprzedał rodzinie Bonerów wojnowickie dobra wraz

16 1529/30: gutten ryttersytz w Borowej k. Oleśnicy; 1530/39: guetten ryttersytze w Gołębicach k. Oleśnicy; 1530: eyn gutt rittersytz w Ligocie Polskiej k. Oleśnicy; 1530: gutten ryttersytz w Lubskach k. Namysłowa; 1530: gutter ryttersytz w Miodarach k. Oleśnicy; 1530: ryttersitz w Poniatowicach k. Oleśnicy (Pfotenhauer 1887, 323-336, przyp. $9,10,55)$.

17 Jako przykłady można podać: 1541: Brochocin k. Trzebnicy (Pfotenhauer 1887, 350, przyp. 116); 1553: Ratyń k. Wrocławia (RF, III, 2081); 1548: Witków k. Szprotawy; 1559: Rittersitz i alten Rittersitz w Chotkowie k. Żagania (Nowakowski 2008, 446, 556); 1569: hoffe oder Ritersitz w Siedlęcinie (Adamska 2016, 73). z siedzibą [Rittersitz] (RF, IV, 2983, 2986; Rozpędowski 1978, 496-497; Chorowska 2003, 184-185).

\section{Zakończenie}

Analiza średniowiecznej nomenklatury siedzib pańskich oraz jej konfrontacja z zachowanymi w terenie reliktami pozwala na wyciągnięcie kilku wniosków. Rezultatem używania w piśmiennictwie łaciny i języka niemieckiego był fakt, że większość spotykanych w dokumentach terminów ma swoje odpowiedniki w obu językach. Ponadto spotykamy zestawienia określeń połączonych spójnikami seu/oder, co świadczy, że traktowano je jako synonimy. Używanie przez śląskich pisarzy wachlarza terminów, stosowanie zestawień synonimicznych, jak i różnych określeń dla tych samych obiektów potwierdza obserwacje innych badaczy, że w średniowiecznych kancelariach nie wypracowano jednolitego nazewnictwa dla założeń obronno-rezydencjonalnych (Nowak, Szymczak 1993, 81; Kołodziejski 1994, 13). Z konfrontacji średniowiecznej nomenklatury z danymi archeologicznymi i architektonicznymi wynika, że bardzo często pod tym samym określeniem kryły się obiekty, które różniły się od siebie wielkością i rodzajem materiałów użytych do ich budowy. Przykładami ilustrującymi powyższą obserwację są obiekty, w odniesieniu do których stosowano terminu curia/Hof - najczęściej spotykanego w źródłach. Ze względu na słabe zaawansowanie stanu badań, niewiele można powiedzieć o trzynastowiecznych dworach. W kolejnym stuleciu identyfikować je można przede wszystkim $\mathrm{z}$ obiektami typu motte, chyba w większości wypadków o lekkiej zabudowie drewniano-glinianej. Założenia murowane $\mathrm{z}$ tego czasu znane są przede wszystkim z Przedgórza Sudeckiego, co znalazło odzwierciedlenie $\mathrm{w}$ terminologii z kancelarii księstw świdnickiego i jaworskiego (curia murata/gemauerter Hof).

Interesujące są też wyniki analizy terminu dwór w zestawieniu $\mathrm{z}$ innymi określeniami. W świetle zebranych materiałów, po połowie XIV w. nastąpiło wyraźne rozdzielenie właściwej siedziby pańskiej i gospodarczego dworu, co znalazło wyraz w powszechności stosowania określenia Hofe und Gesesse. Nie mniej ciekawe są wzajemne relacje terminów dwór i folwark, szczególnie w zestawieniach typu curia allodii, allodium et curia, Hofe und Vorwerk czy też Gute oder Hofe. Śladem bliskiego związku siedzib pańskich i folwarków są ich wzajemne relacje prze- 
strzenne. Bardzo często zachowane w terenie relikty średniowiecznych obiektów obronno-rezydencjonalnych położne są w sąsiedztwie nowożytnych folwarków. W tym kontekście szczególną wartość ma zidentyfikowanie w terenie folwarków Katzenschinder i Egilsjagt.

Od pierwszej połowy XIV w. używano określeń propugnaculum/Bergfried, głównie dla założeń położonych w okolicy Wrocławia. Większość z nich zniszczyła rozbudowa aglomeracji miejskiej. Na podstawie dobrze zachowanych i znanych archiwaliów obiektów można przypuszczać, że za określeniami tymi kryły się okazałe założenia typu motte, najpewniej z murowanymi ceglanymi wieżami mieszkalnymi (Mokra). W źródłach pisanych termin wieża [turris/ Turm] pojawia się jednak sporadycznie. W sposób szczególny określony został obiekt z Pastuchowa [steynwerk, steynnenthurme], najpewniej jedyna murowana budowla w obrębie tamtejszego dworu.

W dokumentacji odnajdujemy także zestaw terminów odnoszących się do poszczególnych elementów składowych siedzib pańskich, takich jak działki i grunty, na których je budowano [area habitationis, ortum pro habitatione facienda], położone $\mathrm{w}$ ich sąsiedztwie człony gospodarcze [Hof], gdzie mieszkała czeladź dworska [hofeleute]. Częściej odnotowywano elementy obronne, takie jak nasypy, na których budowano domy mieszkalne [Wall, mons, Berg, kopiec] oraz otaczające je fosy [fossatum/Graben] i wały [Wall]. Incydentalnie były wzmiankowane innego typu fortyfikacje, takie jak znana z Kościerzyc palisada [blanken], czy też zapewne basteje [Fuhrwergken], na budowę których zgodę uzyskał właściciel dworu w Stabłowicach.

O obronnym charakterze średniowiecznych siedzib pańskich świadczą określenia takie jak castrum/ Burg, Haus, Feste, fortalicium, a incydentalnie także inne. Pierwszych dwóch używano przede wszystkim w odniesieniu do warowni budowanych przez władców terytorialnych. Niektóre z nich identyfikować możemy z tzw. późnymi kasztelaniami. Niekiedy w źródłach występują także obiekty, które jako zamki [castra] funkcjonowały przede wszystkim ,na papierze", natomiast realnie były to małe założenia, wobec których stosowano także określenia castellum i municium. Te jednak nie były terminami często używanymi w źródłach śląskich. Popularności w tutejszych kancelariach nie zdobyło również, powszechne w źródłach polskich, określenie fortalicium. Jego odpowiednikiem było znane z źródeł niemieckojęzycznych Veste/Feste i incydentalnie użyte tvrz. Ostatni termin, podobnie jak znane z pojedynczego przekazu sidlo, znamy z księstw górnośląskich, pozostających pod silnym wpływem czeskim, co przejawiało się m.in. używaniem języka czeskiego w piśmiennictwie.

Termin Hus/Haus stosowano przede wszystkim dla obiektów książęcych, przeważnie dużych murowanych założeń o rozwiniętych programach architektonicznych, rzadziej dla obiektów o zredukowanej formie. W średniowieczu określenie Hus/Haus często traktowano jako synonim castrum/Burg, co oznaczało po prostu zamek. Jak wykazały studia nad budownictwem obronno-rezydencjonalnym księstwa głogowskiego, niekiedy nazywano tak obiekty rycerskie, jednak przeważnie te zbudowane na miejscu starszych warowni książęcych (Nowakowski 2008, 246).

W źródłach z XV w. wiejskie siedziby feudalne nadal wymieniane były jako Hof i Gesesse, jednak coraz częściej nazywano je Sitz. Od drugiej połowy stulecia incydentalnie występuje termin Rittersitz, którym podkreślano przynależność stanową właściciela rezydencji. Określenie to zyskało na popularności w pierwszych dziesięcioleciach XVI w. i było używane w kolejnych wiekach. Pojawienie się terminu Rittersitz może mieć związek z postępującym procesem emancypacji rycerstwa, obserwowanym na Śląsku od 2. poł. XIV w. Według Tomasza Jurka dopiero w XV w. śląskie rycerstwo zamknęło się w odrębny stan, a fundamentalne znaczenie dla tego procesu miało stopniowe wprowadzanie prawa wyłączności nabywania nowych lenn (Jurek 1996, 173-174).

Podsumowując, można zaobserwować pewne ogólne prawidłowości związane ze średniowieczną nomenklaturą dotyczącą niewielkich siedzib pańskich. W pewnym stopniu terminologia odpowiadała charakterystyce obiektów warownych w obowiązującym na Śląsku Zwierciadle Saskim, w którym wyraźnie określono różnicę między zamkiem a innego typu ufortyfikowanymi wiejskimi siedzibami. Obiekty należące do władców terytorialnych, nawet te niewielkich rozmiarów, występują w źródłach jako castrum - Burg - Haus - Schloss. Z kolei w odniesieniu do założeń zbudowanych z inicjatywy wasali książęcych (rycerzy, mieszczan, sołtysów) najczęściej używano określeń curia - Hof - Gesesse - Sitz - Rittersitz. Mając jednak na uwadze opisane przykłady przenikania się znaczeniowego poszczególnych terminów oraz ich wieloznaczność, podkreślić należy, że na podstawie stosowanej w średniowiecznych źródłach śląskich nomenklatury obiektów obronno-rezydencjonalnych nie można wyciągać kategorycznych wniosków, ani odnośnie ich formy, ani wielkości. 


\section{BIBLIOGRAFIA}

\section{Źródła niepublikowane:}

AAWr. - Archiwum Archidiecezjalne we Wrocławiu (dalej: AAWr.), Dokumenty z sygnaturami alfabetycznymi. AAWr. - Dokumenty z sygnaturami chronologicznymi. APWr. - Archiwum Państwowe we Wrocławiu (dalej: APWr.), Akta m. Wrocławia, sygn. B 89: 2 i B 89: 4. APWr., Rep. 4f (Księstwo opolsko-raciborskie), sygn. 151. APWr., Rep. 21 (Księstwo brzeskie), sygn. 1A. APWr., Rep. 31 (Księstwo nyskie), sygn. 1A, 2A APWr., Rep. 33 (Księstwo oleśnickie), sygn. 1242. APWr., Rep. 39 (Księstwo świdnicko-jaworskie), nr 39, 44. APWr., Rep. 66 (Klasztor Krzyżowców z Czerwoną Gwiazdą św. Macieja we Wrocławiu)

APWr., WSPŚ - Wydział Samorządowy Prowincji Śląskiej, Kr. Strehlen, sygn. 770.

NAP, RML - Národní archiv Praha, Maltézští rytíři - české velkopřevorství (1085-1875).

RF - Repertorium Frobenianum (Repertorium Investiturarum in Praediis Ducatus Vratislaviensis, quae in Libris eiusdem Cancellariae continentur), t. 1-4, APWr., Akta miasta Wrocławia, sygn. C 24, I-IV.

RSL - Regesten Saganer Lehnbriefe vor 1510, opr. G. Steller, Kiew 1941 (maszynopis w Bibliotece Uniwersyteckiej we Wrocławiu, sygn. 17772 III).

\section{Źródla publikowane:}

Annales - Annales Glogovienses bis zum Jahre 1493 nebst urkundlichen Beilagen, wyd. H. Markgraf, (w:) Scriptores Rerum Silesiacarum, t. 10, Breslau 1877.

Der Sachsenspiegel - Der Sachsenspiegel aus Oppeln und Krakau, wyd. I. Tapani Piirainen, W. Waßer, Schriften der Stiftung Haus Oberschlesien, Landeskundliche Reiche, t. 10, Berlin 1996.

Eschenloer I - Peter Eschenloer Historia Wratislaviensis, wyd. H. Markgraf, (w:) Scriptores Rerum Silesiacarum, t. 7, Breslau 1872.

Eschenloer II - Peter Eschenloer Geschichte der Stadt Breslau, wyd. G. Roth, New York-München-Berlin 2003.

GHus. - Geschichtsquellen der Hussitenkriege, wyd. C. Grünhagen, (w:) Scriptores Rerum Silesiacarum, t. 6, Breslau 1871.

Inv. Glog. - Die Inventare der nichtstaatlichen Archive Schlesiens, Kreis und Stadt Glogau, wyd. K. Wutke, (w:) Codex Diplomaticus Silesiae, t. 28, Breslau 1915.

Inv. Grünb. - Die Inventare der nichtstaatlichen Archive Schlesiens, Die Kreise Grünberg und Freystadt, wyd.
K. Wutke, (w:) Codex Diplomaticus Silesiae, t. 4. 24, Breslau 1908.

Inv. Nei. - Die Inventare der nichtstaatlichen Archive Schlesiens, Neisse. I. Stadt Neisse, wyd. E. Graber, (w:) Codex Diplomaticus Silesiae, t. 36, z. 1, Breslau 1933.

KDW - Kodeks dyplomatyczny Wielkopolski, t. II, wyd. I. Zakrzewski, Poznań 1878.

KH - Księga henrykowska, wyd. R. Grodecki, Wrocław 1991.

Kronika - Kronika polska, wyd. L Ćwikliński, (w:) Monumenta Poloniae Historica, t. III, Kraków 1878, s. 578-656.

Lehns - Lehns- und Besitzurkunden Schlesiens und seiner einzelnen Fürstenthümer im Mittelalter, t. I-II, wyd. C. Grünhagen, H. Markgraf, (w:) Publicationen aus den königlichen preußischen Staatsarchiven, t. 7, 16, Leipzig 1881-1883.

Lf - Liber fundationis Episcopatus Vratislaviensis, wyd. H. Markgraf, J. W. Schulte, (w:) Codex Diplomaticus Silesiae, t. 14, Breslau 1889.

LKŚJ - Landbuch księstw świdnickiego i jaworskiego, t. I: 1366-1376, wyd. T. Jurek, Poznań 2004; t. II: 13851395, wyd. T. Jurek, Poznań 2000; t. III: 1396-1407, wyd. T. Jurek, Poznań 2007.

LOR - Die Landbücher von Oppeln-Ratibor, wyd. J. Chrząszcz, „Oberschlesische Heimat”, t. 10, 1914, s. $24-34,123-132,174-182$; t. 11,1915 , s. 76-84, t. 12 , 1916, s. 97-102.

PBD - Protokolle des Breslauer Domkapitels, Fragmente aus der Zeit 1393-1460, wyd. C. Grünhagen, „Zeitschrift des Vereins für Geschichte Schlesiens”, t. 5, 1863, s. 118-159.

Pfotenhauer - Adel des Fürstenthums Oels im 16. Jahrhundert, opr. P. Pfotenhauer, ,Zeitschrift des Vereins für Geschichte Schlesiens", t. 21, 1887, s. 318-368.

QGNB - Quellen zur Geschichte des Neisser Bistumslandes auf Grund der drei ältesten Neisser Lagerbücher, wyd. K. Engelbert, (w:) Quellen und Darstellungen zur schlesischen Geschichte, Würzburg 1964.

Rachunki - Rachunki dworu króla Władysława Jagiełły i królowej Jadwigi z lat 1388-1420, wyd. F. Piekosiński, (w:) Monumenta medii aevi historica, t. 15, Kraków 1896.

RS - Regesten zur schlesischen Geschichte, wyd. C. Grünhagen, K. Wutke, (w:) Codex diplomaticus Silesiae, t. 16, 18, 22; wyd. K. Wutke, (w:) Codex diplomaticus 
Silesiae, t. 29; wyd. K. Wutke, E. Randt, (w:) Codex diplomaticus Silesiae, t. 30, Breslau 1892-1930.

RSB - Henricus Pauper. Rechnungen der Stadt Breslau von 1299-1358, nebst zwei Rationarien von 1386 und 1387 , dem liber imperatoris vom Jahre 1377 und den ältesten Breslauer Statuten, wyd. C. Grünhagen, (w:) Codex Diplomaticus Silesiae, t. 3, Breslau 1860.

RSW - Registrum St. Wenceslai. Urkunden vorzüglich zur Geschichte Oberschlesiens nach einen Copialbuch Herzog Johannis von Oppeln und Ratibor in Auszügen mitgeteilt, wyd. W. Wattenbach, C. Grünhagen, (w:) Codex Diplomaticus Silesiae, t. 6, Breslau 1865.

Rś - Regesty śląskie, t. I-V, red. W. Korta, Wrocław 19751992

Reg. Wrat. - Das Registrum Wratislaviense censuum et reddituum ad episcopatum spectantium, wyd. W. Schulte, (w:) Darstellungen und Quellen zur schlesischen Geschichte, t. 3, Breslau 1907, s. 204-260.

SUb - Schlesisches Urkundenbuch, t. I, wyd. H. Appelt; t. II-VI, wyd. W. Irgang, Wien-Köln-Graz 1971-1998.

SWŚ - Słownik wsi śląskich w średniowieczu, t. 1: Powiat lubiński, opr. D. Adamska, A. Latocha, D. Nowakowski, A. Paroń, M. Siehankiewicz, R. Sikorski, Wrocław 2014.

UGBB - Urkunden zur Geschichte des Bisthums Breslau im Mittelalter, wyd. G. A. Stenzel, Breslau 1845.

UHLB - Urkunden Herzog Ludwig I. von Brieg, wyd. R. Rösler, „Zeitschrift des Vereins für Geschichte Schlesiens", t. 6, 1864, s. 1-96, t. 11, 1872, s. 429-462.

USB - Urkunden der Stadt Brieg, wyd. C. Grunhagen, (w:) Codex Diplomaticus Silesiae, t. 9, Breslau 1870.

\section{Literatura:}

Adamska D. (2005). Fundacje dewocyjne rycerstwa księstwa świdnicko-jaworskiego w średniowieczu. Poznań-Wrocław: Wydawnictwo Historyczne.

Adamska D. (2006). O wołowskim staroście Janie von Debitsch w świetle źródeł archeologicznych, ikonograficznych i pisanych. W: S. Rosik, P. Wiszewski (red.), Mundus hominis - cywilizacja, kultura, natura (515-523). Wrocław: Wydawnictwo Uniwersytetu Wrocławskiego.

Adamska D. (2016). Siedlęcin, czyli „wieś Rudigera”. Studia nad średniowiecznym osadnictwem wokół Jeleniej Góry. W: P. Nocuń (red.), Wieża książęca $w$ Siedlęcinie $w$ świetle dotychczasowych badań (37-73). Siedlęcin-Pękowice-Kraków: Profil-Archeo, Instytut Archeologii Uniwersytetu Jagiellońskiego.
Adamska D. (2019). Wieś - miasteczko-miasto. Średniowieczne osadnictwo $w$ dorzeczu górnej i środkowej Oławy. Łomianki: LTW

Andrzejewski T. (2007). Rechenbergowie $w \dot{z} y c i u$ społeczno-gospodarczym księstwa głogowskiego w XVI-XVII wieku. Zielona Góra: Oficyna Wydawnicza Uniwersytetu Zielonogórskiego.

Binding G. (1980). Bergfried. Lexikon des Mittelalters, t. I, München, 1955-1956.

Błoniewski P. (2017). Zamki rycerskie w księstwie świdnickim. Wrocław (niepublikowana praca doktorska przechowywana w archiwum Katedry Historii Architektury, Sztuki i Techniki Politechniki Wrocławskiej).

Boguszewicz A. (2001). Nienawiść Rudego Smoka do Bolesława a geneza zamków romańskich na Śląsku. W: J. Wasilewski (red.), Zamek i dwór w średniowieczu od XI do XV wieku (18-23). Poznań: Wydawnictwo Poznańskiego Towarzystwa Przyjaciół Nauk.

Boguszewicz A. (2005). Architektura siedziby możnowładczo-rycerskiej w Wierzbnej koło Świdnicy w świetle badań archeologicznych. Archaeologica Historica Polona, 15(1), 279-307.

Boguszewicz A. (2010a). Corona Silesiae. Zamki Piastów fürstenberskich na południowym pograniczu księstwa jaworskiego, świdnickiego i ziębickiego do połowy XIV wieku. Wrocław: Wydawnictwo Uniwersytetu Wrocławskiego.

Boguszewicz A. (2010b). Zamki a konflikty zbrojne na Śląsku w drugiej połowie XV wieku. W: T. Ciesielski (red.), Zamki, twierdze i garnizony Opola, Ślaska i dawnej Rzeczypospolitej (12-38). Zabrze: Wydawnictwo Inforteditions.

Boguszewicz A. (2012). Początki zamków prywatnych w Europie Środkowowschodniej. Silesia Antiqua, 48, 109-142.

Bouard, M. de (1967). Quelques données françaises et normandes concernant le problème de l'origine des mottes. Château Gaillard, 2, 19-26.

Chorowska M. (2002). Zamek jako rezydencja książęca na Dolnym Śląsku w XIII wieku na tle zachodnioeuropejskim. W: M. Antoniewicz (red.), Zamki i przestrzeń społeczna w Europie Środkowej $i$ Wschodniej (182208). Warszawa: Wydawnictwo DiG.

Chorowska M. (2003). Rezydencje średniowieczne na Śląsku. Zamki, pałace, wieże mieszkalne. Wrocław: Oficyna Wydawnicza Politechniki Wrocławskiej.

Degen K. (1965). Die Bau- und Kunstdenkmäler des Landkreises Breslau, Bau- und Kunstdenkmäler des deutschen Ostens, R. C: Schlesien, I, Frankfurt a. Main: Verlag Wolfgang Weidlich. 
Deutsches Wörterbuch von Jacob Grimm und Wilhelm Grimm (http://dwb.uni-trier.de/de/).

Dobrzański S. J. (1978). Castrum. Problematyka badawcza. Prace Naukowe Instytutu Historii Architektury, Sztuki i Techniki Politechniki Wrocławskiej, 12, Studia i Materiaty, 5, 5-21.

Eistert K. (1931). Die untergegangene Burg Malgost bei Zedlitz, Kr. Ohlau. Unser Schlesien, dodatek do Ohlauer Kreis-und Stadtblatt, nr 10/25.05.1931 i 11/08.06.1931.

Eistert K. (1936). Historische Burgwallforschung im Kreise Ohlau. Altschlesische Blätter, 11, 43-45.

Eysymontt K. (2010). Architektura renesansowych dworów na Dolnym Śląsku. Wrocław: Muzeum Architektury we Wrocławiu.

Goliński M. (1991). Krzyżacy czy joannici? W sprawie rzekomej obecności joannitów pod Wrocławiem w 1273 r. Ślacki Kwartalnik Historyczny Sobótka, 46(3), 341-344.

Goliński M. (2005). Książę, biskup i zamki. W: E. Różycka-Rozpędowska, M. Chorowska (red.), Nie tylko zamki. Szkice ofiarowane Profesorowi Jerzemu Rozpędowskiemu $w$ siedemdziesiąta piata rocznicę urodzin (41-53). Wrocław: Oficyna Wydawnicza Politechniki Wrocławskiej.

Goliński M. (2014). Miasto, książę i zamki. W: S. Sochacka, P. Jusiak (red.), Scientia nihil est quam veritatis imago. Studia ofiarowane Profesorowi Ryszardowi Szczygłowi w siedemdziesięciolecie urodzin (793834). Lublin: Wydawnictwo UMCS.

Goliński M. (2017). Zapomniany zamek monarszy w Borowie. Ślaski Kwartalnik Historyczny Sobótka, 72(2), 31-48.

Grundmann G. (1982). Burgen, Schlösser und Gutshäuser in Schlesien, Bd. I: Die mittelalterlichen Burgruinen und Wohntürme. Frankfurt a. Main: Verlag Wolfgang Weidlich.

Guerquin B. (1984). Zamki w Polsce. Warszawa: Wydawnictwo Arkady.

Haeusler W. (1883). Geschichte des Fürstenthums Oels bis zum Austerben der Piastischen Herzogslinie. Breslau: Josef Max \& Comp.

Heś R. (2007). Joannici na Śląsku w średniowieczu. Kraków: Wydawnictwo Avalon.

Heyne J. (1860). Dokumentierte Geschichte des Bisthums und Hochstiftes Breslau. Aus Urkunden, Aktenstücken, älteren Chronisten und neueren Geschichtsschreibern, Bd. I. Breslau: Verlag Wilhelm Gottlieb Korn.

Hinz H. (1981). Motte und Donjon. Zur Frühgeschichte der mittelalterlichen Adelsburg. Zeitschrift für Archäologie des Mittelalters, Beiheft 1. Köln: RheinlandVerlag.
Historisches Ortsverzeichnis von Sachsen (https://hov.isgv. $\mathrm{de} /$ ).

Jóźwiak S., Trupinda J. (2012). Krzyżackie zamki komturskie $w$ Prusach. Topografia i układ przestrzenny na podstawie średniowiecznych źródet pisanych. Toruń: Wydawnictwo Naukowe Uniwersytetu Mikołaja Kopernika.

Jurek T. (1996). Obce rycerstwo na Śląsku do połowy XIV wieku. Poznań: Wydawnictwo Poznańskiego Towarzystwa Przyjaciół Nauk.

Jurek T. (2012). Abstructores castrorum. Przyczynek do dziejów społecznych i politycznych Śląska w połowie XIII wieku. W: W. Bukowski, T. Jurek (red.), Narodziny Rzeczpospolitej. Studia z dziejów średniowiecza i czasów wczesnonowożytnych, t. 2. (767-786). Kraków: Wydawnictwo Societas Vistulana.

Kajzer L. (1993). Zamki i społeczeństwo. Przemiany architektury i budownictwa obronnego w Polsce $w$ X-XVIII wieku. Łódź: Wydawnictwo Uniwersytetu Łódzkiego.

Kajzer L. (2010). Dwory w Polsce od średniowiecza do współczesności. Warszawa: DiG

Kajzer L., Kołodziejski S., Salm J. (2001). Leksykon zamków w Polsce. Warszawa: Wydawnictwo Arkady.

Kašička F. (1985). Hospodářské zázemí drobných feudálních sídel ve středních Čechách. Archaeologia historica, 10, 57-65.

Kąsinowska R. (2003). Architektura rezydencjonalna powiatu nowosolskiego. Nowa Sól: Muzeum Miejskie w Nowej Soli.

Kiarszys G. (2015). Iuxta castrum Sandouel. Trzy światy średniowiecza. Szczecin: Wydawnictwo Uniwersytetu Szczecińskiego.

Kratzke Ch. (2005). Vorwerk. W: W. Paravicini (red), Höfe und Residenzen im spätmittelalterlichen Reich. Bilder und Begriffe (178-179). Ostfildern: Jan Thorbecke Verlag.

Kunstmann H. (1967). Mensch und Burg. Burgenkundliche Betrachtungen an ostfränkischen Wehranlagen. Würzburg: Kommissionsverlag Ferdinand Schöningh.

Legut-Pintal M. (2017). Zamki księstwa nyskiego na tle przemian krajobrazu kulturowego w średniowieczu. Wrocław: Oficyna Wydawnicza ATUT.

Lorenz K. (1939). Urkundliches über Wehranlagen im Neisser Lande. Jahresbericht des Kunst- und Altertumsvereins Neisse, 40/42, 13-18.

Marciniak A. (1991). Budownictwo obronne w Liber beneficiorum Jana Długosza a realia archeologiczne. Acta Universitatis Lodziensis. Folia Archaeologica, 12, 161-198.

Nekuda V., Unger J. (1981). Hrádky a tvrze na Moravě. Brno: Nakladatelství Blok v Brně. 
Nocuń P. (2019). Zamek w Chudowie do końca XVI w. - rozwój i przekształcenia prywatnej siedziby górnośląskiej w świetle dotychczasowych badań. Architectus, 57(1), 67-78.

Nowak T., Szymczak J. (1993). Obiekty obronne w Sieradzkiem i Wieluńskiem w świetle źródeł pisanych. W: T. J. Horbacz, L. Kajzer (red.), Między Północa a Poludniem. Sieradzkie i Wieluńskie $w$ późnym średniowieczu i czasach nowożytnych (81-95). Sieradz: Państwowa Służba Ochrony Zabytków, Oddział Wojewódzki w Toruniu.

Nowakowski D. (2008). Siedziby książęce i rycerskie księstwa głogowskiego w średniowieczu. Wrocław: Wydawnictwo IAE PAN.

Nowakowski D. (2017a). Ślaskie obiekty typu motte. Studium archeologiczno-historyczne. Wrocław: Wydawnictwo IAE PAN.

Nowakowski D. (2017b). W sprawie identyfikacji zaginionych średniowiecznych wsi i folwarków na Śląsku z perspektywy badań nad obiektami typu motte. W: D. Adamska, K. Chrzan, A. Pankiewicz (red.), Cum gratia et amicitia. Studia z dziejów osadnictwa dedykowane Pani Profesor Marcie Mtynarskiej-Kaletynowej z okazji 65-lecia działalności naukowej (221-234). Wrocław: Wydawnictwo IAE PAN, Uniwersytet Wrocławski.
Pfeifer G. (1929). Das Breslauer Patriziat im Mittelalter. Darstellungen und Quellen zur schlesischen Geschichte, Bd. 30. Breslau: Trewend \& Granier.

Plaček M. (2001). Ilustrovaná encyklopedie moravských hradì, hrádků a tvrzí. Praha: Nakladatelství Libri.

Poliński D. (2018). Gród czy zamek? Desygnaty terminów oraz konsekwencje ich stosowania w archeologii historycznej i ochronie zabytków. Archeologia Historica Polona, 26, 41-58.

Rozpędowski J. (1978). Późnogotyckie rezydencje na Śląsku. W: P. Skubiszewski (red.), Sztuka i ideologia XV wieku (493-520). Warszawa: Państwowe Wydawnictwo Naukowe.

Słownik łaciny średniowiecznej w Polsce, t. I, II, IV, VI, red. M. Plezia, Warszawa 1953-1992.

Steller G. (1940). Grund- und Gutsherren im Fürstentum Sagan /1400-1940/. Sagan: Verlag W. Daustein.

Svoboda L., Úlovec J., Chotěbor P., Procházka Z., Fišera Z., Anderle J., Slavík J., Rykl M., Durdík T., Brych V. (opr.) (1998). Encyklopedie českých tvrzí, I-III. Praha: Nakladatelství ARGO.

Zimmermann F.A. (1785). Beyträge zur Beschreibung von Schlesien, 4. Breslau: Johann Ernst Tramp.

\title{
DOMINIK NOWAKOWSKI
}

\section{MANOR HOUSES IN SILESIA IN LIGHT OF WRITTEN SOURCES: A STUDY OF MEDIEVAL NOMENCLATURE}

\author{
SUMMARY
}

As a result of the cultural transformations of the 13th century, previously unknown types of the castles and manor houses emerged in the areas east of the Odra river (Oder). The leading role of Śląsk (Silesia) in the development of castle building has been emphasized many times in the literature. Compared to other historical regions of the Kingdom of Poland, this province has the greatest number of medieval castles, including examples of the very oldest objects (Guerquin 1984, p. 25; Kajzer, Kołodziejski, Salm 2001, pp. 30-34; Boguszewicz 2001; Chorowska 2002). This can also be said of small residences built by ducal vassals. Formally they represent different variants, the most popular of them being motte-and-bailey. Masonry objects are mainly residential towers, sometimes also built on earth mounds. Less common and usually younger are residences with more developed architectural forms, such as one- or two-wing manors (Rozpędowski 1978; Pawłowski 1984; Jacaszek 1996; Chorowska 2003, pp. 131-151, 166-194; Boguszewicz 2012; Nowakowski 2017a).

In the literature, the medieval nomenclature regarding castles and manor houses has rarely been the subject of separate studies (Kunstmann 1967, pp. 1-34; Marciniak 1991; Nowak, Szymczak 1993). In Śląsk, analyses of medieval terminology was undertaken by studies about motte-andbailey castles (Nowakowski 2017a, pp. 79-89). Many interesting conclusions on this issue can also be found in Ma- 
teusz Goliński's articles about conflicts between the Silesian dukes and bishops, and the financial support of Wrocław's citizens for expeditions against the castles (Goliński 2005, 2014). Recently, Dariusz Poliński paid attention to the medieval nomenclature of defensive structures, returning to the discussion from years ago on the meanings of the terms gród (early medieval stronghold) and zamek (medieval castle) (Poliński 2018, pp. 47-51).

Analysis of the nomenclature used in medieval Silesian sources and their confrontation with the relics of small manor houses allows us to draw several conclusions. Silesian writers in the Middle Ages used Latin, which in time was replaced by German - therefore, many terms have their equivalents in both languages: curia/Hof, curia murata/ gemauerte Hof, castrum/Burg, propugnaculum/Bergfried, turris/Turm. Our documents also yield combinations which expressly show that some terms were treated as synonyms: municio seu curia, municio seu fortalicium, castrum seu fortalicium, Gesäß oder Hoff, Walle oder Veste. In addition, we know objects from the sources that were noted incidentally, as well as those that were mentioned many times. This proves the ambiguity of the terms used in medieval documents. These observations are confirmed by the results of archaeological and architectural research, which in confrontation with medieval terminology suggest that very often different objects were described with the same terms. The best example of this is the most commonly used term curia/Hof.

Due to the state of research, we cannot say much about manor houses from the 13th century. In the 14th century, they can be identified mainly with the objects of motte-andbailey type, probably with light timber-clay buildings. Masonry objects, present among other reasons because of the easy availability of raw material, appeared in the south of Śląsk (Silesia), which was confirmed in the nomenclature: curia murata/gemauerte Hof. The residential character of medieval manors was confirmed in the written sources by the terms curia habitationis/Wohnhof.

The defensive character of some objects is confirmed by the terms castrum/Burg, Feste, fortalicium, along with random others. The first two primarily describe ducal foundations that we can sometimes identify with late castellan castles. As Mateusz Goliński notes, in some cases it may be suspected that the use of the term castrum in documents may have been a deliberate abuse of ducal and episcopal chancelleries, intended to justify seizures against such objects (Goliński 2005). It is known that in light of medieval law - Sachsen Spiegel known in Śląsk as versio Vratislaviensis - only territorial rulers could build castles. With- out the duke's consent, only small residential objects with a clearly defined form could be built (Der Sachsenspiegel..., pp. 88-89). So from the legal point of view, armed measures were justified only against objects that violated the castle regalia. In the written sources we also find objects that functioned as castles only "on paper", while in reality they were relatively small structures.

From the first half of the 14th century, mainly in the case of a few objects located near Wrocław, the terms propugnaculum/Bergfried were used. Unfortunately, most of these objects were destroyed. On the basis of archival data and the few preserved examples it can be assumed that these were large motte objects, most probably with brick residential towers.

In light of the materials collected, after the middle of the 14th century, the most popular term for small residence was Gesesse. Around the same time our written sources stress a clear separation between the residential house and farm buildings, something evinced in the commonly used expression Hofe und Gesesse. Some of these can be identified as small motte castles mostly without a bailey, but with a manor farm (Vorwerk), and as brick and stone residential towers. In the written sources we can see a close connection between manor houses and farms, for example in such expressions as: allodium et curia, curia allodii and Gute oder Hofe. We know examples which had a habitable function (statio/Einquartierungsrecht), as well examples of fortified manor farms well-preserved in the landscape (Nowakowski 2017b).

The written sources also contain several terms for particular defensive elements of small residences, such as moat (fossatum/Graben), motte (mons castri/Berg/Wall/kopiec), timber-earth wall (Wall), palisade (blanken) as well the places where they were built (area habitationis, ungebauten Hof), but these are all rare.

In the 15 th century, the previously popular terms Hof and Gesesse were still used for rural feudal residences. The equivalent for the latter of these is the increasingly common term Sitz. From the second half of the 15 th century the term Rittersitz was also incidentally used (it relative rarity is most probably a result of the state of research on the sources from that period). This term clearly indicated the status of the owner, and its appearance may be related to the process of the knighthood's emancipation.

Finally, it has to be said that because of the ambiguity of the nomenclature used in written sources, it is not possible to draw categorical conclusions on their basis about the size of medieval manor houses and castles. 
Otrzymano (Received): 6.06.2020; zrecenzowano (Revised): 29.10.2020; zaakceptowano (Accepted): 10.11.2020

Adres Autora:

Dr hab. Dominik Nowakowski (prof. IAE PAN)

Ośrodek Badań nad Kulturą

Późnego Antyku i Wczesnego Średniowiecza

Instytut Archeologii i Etnologii PAN

ul. Więzienna 6; 50-118 Wrocław

e-mail:dominik@arch.pan.wroc.pl

(iD https://orcid.org/0000-0003-1735-746 